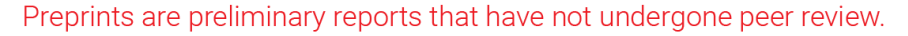 They should not be considered conclusive, used to inform clinical practice, or referenced by the media as validated information. \\ Adsorbent Minimisation for Removal of Ibuprofen from Water in a Two-Stage Batch Process
}

\section{Hajar Farzaneh}

Hamad Bin Khalifa University College of Science and Engineering

Jayaprakash Saththasivam

Qatar Environment and Energy Research Institute

\section{Gordon McKay}

Hamad Bin Khalifa University College of Science and Engineering

Prakash Parthasarathy ( $\nabla$ prakrock@gmail.com )

Hamad Bin Khalifa University College of Science and Engineering https://orcid.org/0000-0003-26354416

\section{Research Article}

Keywords: pharmaceutical adsorption, high removal capacity, waste date stone derived carbon, adsorbent usage minimisation, two-stage batch adsorber optimisation

Posted Date: April 7th, 2021

DOl: https://doi.org/10.21203/rs.3.rs-357748/v1

License: (c) (i) This work is licensed under a Creative Commons Attribution 4.0 International License.

Read Full License 


\title{
Adsorbent Minimisation for Removal of Ibuprofen from Water in a Two- Stage Batch Process
}

\author{
Hajar Farzaneh ${ }^{1}$, Jayaprakash Saththasivam², Gordon McKay ${ }^{1 *}$, Prakash Parthasarathy ${ }^{1 *}$ \\ ${ }^{1}$ Division of Sustainable Development, College of Science and Engineering, Hamad Bin Khalifa University, \\ Education City, Qatar Foundation, Doha, Qatar. \\ ${ }^{2}$ Qatar Energy and Environment Research Institute, Hamad Bin Khalifa University, Education City, Qatar \\ Foundation, Doha, Qatar. \\ *Corresponding author: gmckay@hbku.edu.qa,prakrock@gmail.com,pparthasarathy@hbku.edu.qa
}

\begin{abstract}
\end{abstract}
Pharmaceutical products in water, frequently referred to as personal pharmaceutical products, PCPPs are regarded as problematic emerging pollutants with the potential to cause damaging health and environmental impacts to several ecosystems. In this study, an acid activated carbon has been produced from waste date stones, the waste product obtained from the seedless date products manufacturing industry. This material has been used to remove the pharmaceutical compound ibuprofen from water with a high adsorption capacity of $126 \mathrm{mg}$ ibuprofen per $\mathrm{g}$ waste date stone derived activated carbon. In order to optimise the use of the activated carbon, a design study has been performed to minimise the quantity of carbon needed using a two-stage batch adsorption system. Several variables have been inputted into the design model to test the model and compare the quantities of adsorbent required in the two-stage and the single stage systems under various conditions.

Keywords: pharmaceutical adsorption; high removal capacity; waste date stone derived carbon; adsorbent usage minimisation; two-stage batch adsorber optimisation. 


\section{Introduction}

In recent decades, a myriad of, PPCPs, pharmaceutical personal care products and endocrine-disrupting substances (EDCs), has been frequently identified in the aquatic environment and various water bodies such as treated sewage effluents, surface water, groundwater and drinking water (Tran et al. 2014; De Vargas et al. 2021). The presence of these emerging contaminants, despite in trace amounts, is a growing concern due to their potential adverse toxic effects on aquatic organisms and human health (Nassiri Koopaei and Abdollahi 2017; Gallego-Ríos et al. 2021). One of the primary pathways for these compounds to enter and contaminate potable water resources is via treated sewage effluents (Schröder et al. 2016). As the majority of wastewater treatment plants are designed to remove waste solids, carbon, nitrogen and phosphorus, the conventional treatment processes deployed in these plants are only capable of partially eliminating emerging contaminants as some of these compounds are not biodegradable, highly stable, resist precipitation and remain soluble in the effluent stream (Mestre et al. 2009; Badmus et al. 2018). Studies have indicated that estrogenic compounds found in treated sewage effluents led to the feminization of fish and amphibians (Rathner et al. 2017). It has also being reported that estrogenic compounds could negatively affect and alter the self-endocrine regulation of human (Kishor et al. 2021). Another serious concern caused by emerging contaminants is the development of antibiotic-resistant bacteria and genes (RodriguezMozaz et al. 2015; Kumar and Pal 2018) that could pose a severe health risk to humans and animals.

Advanced tertiary treatment processes, namely, advanced oxidation operations, membrane filtration and adsorption, can be used to enhance the removal of contaminants of emerging concern such as PPCPs and EDCs. Advanced oxidation processes such as ozone, ozone-hydrogen peroxide and UV-hydrogen peroxide have been reported as one of the effective processes in removing emerging contaminants (Westerhoff et al. 2005; Ponnusamy et al. 2019), but these operations may incur higher capital and operating cost for full-scale operation (Borikar et al. 2014; Farzaneh et al. 2020). Formation of by-products of higher toxicity is another concern that is often associated with the usage of advanced oxidation processes (Kudlek 2018). Membrane filtration processes using nanofiltration and reverse osmosis membranes are also capable of removing emerging contaminants. However, the removal efficiency of membrane technologies is greatly governed by the properties of the membrane (molecular weight cutoff (MWCO), hydrophobicity, and surface charge) and the contaminants (MW distribution, hydrophobic /hydrophilic and charge groups of organic material) (Shon et al. 2006). The high membrane fouling potential due to the presence of organic matter is another drawback of using membranes technologies. Adsorption is another 
efficient treatment process that can remove organic contaminants and does not produce any toxic by-products (Golovko et al. 2020; Sadraei 2020).

In this study, ibuprofen is used as a reference compound to evaluate the performance of activated carbon synthesized from local date stones. Almanassra et al. (Almanassra et al. 2020) reported that carbide-derived carbon (CDC) can be effectively used as an adsorbent for the removal of ibuprofen from deionized water and treated sewage effluent. Guedidi et al. (Guedidi et al. 2013) claimed that surface modification of commercial granular activated carbon using hydrogen peroxide as an oxidant, led to the formation of carbonyl groups that aid the adsorption uptake of ibuprofen. Another investigation by Guedidi et al. (Guedidi et al. 2017) that investigated the performance of an activated carbon cloth in removing ibuprofen, showed adsorption kinetics of ibuprofen was higher at lower pH. An investigation by Baccar et al. (Baccar et al. 2012) that studied the removal of ibuprofen along with other pharmaceuticals such as ketoprofen, naproxen and diclofenac using olive-waste cake waste derived activated carbon revealed that contaminant removal efficiency was lower at alkaline $\mathrm{pH}$. In a comparative study applying activated carbon obtained from local plant waste, Mestre et al. (Mestre et al. 2011) reported that ibuprofen had a higher removal efficiency than paracetamol. This was attributed to the electrostatic interactions between the ibuprofen and surface charges of the carbon. Many other studies have reported high quality activated carbons and chars have been produced from waste biomass and other wastes, including: olive stones (Saleem et al. 2019), bagasse (Chen et al. 2001), chitosan (Wong et al. 2004), waste bamboo furniture/scaffolding (Mui et al. 2010b) and vehicle tyres (Mui et al. 2010a). Palm kernel shell was used to investigate the adsorption of three pharmaceuticals (To et al. 2017), namely, atenolol, acebutolol and carbamazepine with adsorption capacities of 154, 165 and 154 $\mathrm{mg} / \mathrm{g}$ respectively. Some studies have reported the production of activated carbons from date stones often termed date pits (Merzougui et al. 2011; Danish et al. 2014) using phosphoric acid (Girgis and El-Hendawy 2002), zinc chloride (Cherik and Louhab 2017) and carbon dioxide (Suresh Kumar Reddy et al. 2013). The methodologies of converting date stones into activated carbons have yielded a variety of pollutant removal applications for this material, such as, pesticides (Hameed et al. 2009; Hassan et al. 2020), dyes (Al-Ghouti et al. 2010; Bouchemal et al. 2012; Messaoudi et al. 2016), heavy metals (Al-Ghouti et al. 2010; Bouhamed et al. 2012; Mangwandi et al. 2020) and pharmaceuticals (Belhamdi et al. 2016; Darweesh and Ahmed 2017).

In the current study the activated carbon has been produced by thermally treating phosphoric acid impregnated powdered waste date stone chars (by pyrolysis at $350-600^{\circ} \mathrm{C}$ ) at $550^{\circ} \mathrm{C}$ for two hours. This carbon has been tested 
experimentally for its adsorption capacity towards ibuprofen and the experimental equilibrium data were analyzed using seven isotherm models. Finally, a model was developed and applied to determine the to optimum use of the activated carbon using a design study performed to minimise the quantity of carbon required using a two-stage batch adsorption system. Several variables have been inputted into the design model to test the model and compare the quantities of adsorbent required in the two-stage and the single stage systems under various conditions.

\section{Materials and Experimental}

\subsection{Raw materials treatment}

Dates stones were provided by a stoneless date food products manufacturer (Bateel Ltd. Qatar). The raw date stones were washed twice with water to remove the soluble impurities from the stones. These washed stones were immersed in nitric acid $(0.1 \mathrm{M})$ for 1 hour, and then in methyl alcohol for $60 \mathrm{~min}$. in order to remove the organic and inorganic material from the date stone surface. This processed date stone material was dried at $140^{\circ} \mathrm{C}$ for 12 hours, crushed/powdered using a hammer mill and then segregated by sieving using BSS-25 sieves followed by storage in a dessicator. Following this step it is suitable for charring and activation. This treated date stone was used as the raw material for the preparation of the activated carbons.

The production methods of activated carbons from the date stones has been reviewed (Hijab et al. 2020) and the particular activation method of the current date stone powder has been described previously (Hijab et al. 2020). The waste date stone derived activated carbon used in the present study was based on a modified phosphoric acid activation (PAA) process used by Hijab et al. (Hijab et al. 2020).

The first stage treatment was thermal treatment to produce a char product. This was followed by the chemical activation of the charred date stone powdered material by $30 \%(\mathrm{w} / \mathrm{w})$ orthophosphoric acid using a 1:1 (w/w) ratio of acid: date stone char.

\subsection{Ibuprofen}

Ibuprofen (IBU) obtained from Sigma-Aldrich company was used in the preparation of $40 \mathrm{mg} / \mathrm{L}$ concentration stock solution in Type I ultrapure water (PW) having a resistivity value $18.0 \mathrm{M} \Omega . \mathrm{cm}$. The characteristic properties of the pharmaceutical are shown in Table 1. The stock solution of ibuprofen, IBU, was prepared using sonication for one hour at $60^{\circ} \mathrm{C}$, and HPLC analysis was performed to measure and confirm the concentration of the ibuprofen stock solution. The concentrations of all ibuprofen solutions in this study were 

maintained and stored at $4^{\circ} \mathrm{C}$.

Table 1. Ibuprofen properties

\begin{tabular}{ll}
\hline Property & Ibuprofen \\
\hline Chemical formula & $\mathrm{C}_{13} \mathrm{H}_{18} \mathrm{O}_{2}$ \\
& \\
Chemical structure & $206.28 \mathrm{~g} / \mathrm{mol}$ \\
Molecular weight & Solid \\
Physical state & $76^{\circ} \mathrm{C}$ \\
Melting point & $157^{\circ} \mathrm{C}$ \\
Boiling point & 4.91 \\
pKa & 3.97 \\
log $\mathrm{K}_{\text {ow }}$ & $21 \mathrm{mg} / \mathrm{L}$ \\
Water solubility & \\
${ }^{*}$ measured at $25^{\circ} \mathrm{C}$. &
\end{tabular}

\subsection{Derived date stone adsorbents preparation}

The product was based on an acidified date stone powder being activated by thermal treatment - heating at

$113550^{\circ} \mathrm{C}$. The initial treatment stage was the thermal treatment of the raw date stone powder in the range of 350 to $114600^{\circ} \mathrm{C}$ to produce an intermediate char product using a Carbolite furnace purged with nitrogen. Next chemical 115 activation was performed by adding $30 \%(\mathrm{w} / \mathrm{w})$ orthophosphoric acid in a 1:1 (w/w) ratio of acid: date stone char 116 followed by heating the acid/char mix in an inerted muffle furnace, supplied by Carbolite, and purged with nitrogen 117 at $100 \mathrm{~cm}^{3} / \mathrm{min}$. The acid activation process generates a high surface area and places $\mathrm{H}+$ ions on the surface of the 118 date stone carbon. This effect then attracts negatively charged species but it repels positive basic charged species, 119 however, at a higher $\mathrm{pH}$, the $\mathrm{H}+$ ions at the surface can diffuse into the solution generating some available sites with 120 a surplus negative charge to attract the positively charged basic species. Nitrogen gas was flowed through the system 121 for $30 \mathrm{~min}$. prior to pyrolysis. The furnace was cooled to ambient temperature after the activation step while the flow 122 of nitrogen was in operation. The acid activated material was water washed to remove any excess phosphoric acid 
123 of pharmaceutical removed from the initial solution concentration, $\mathrm{C}_{0}$. That is:

Quantity of IBU adsorbed on carbon $=$ Quantity of IBU removed from solution

$m\left(q_{0}-q_{e}\right)=-V\left(C_{0}-C_{e}\right)$

145 Rearranging the equation for $q_{e}$ :

$q_{e}=\frac{V}{m}\left(C_{0}-C_{e}\right)$ 
where, $q_{e}$ is the quantity IBU adsorbed on the solid carbon at equilibrium in $\mathrm{mg} / \mathrm{g}, q_{0}$ is the quantity adsorbed on carbon at time zero, $\mathrm{t}=0$, this is equal to $0, \mathrm{C}_{0}$ and $\mathrm{Ce}$ represent the initial and the final (equilibrium) IBU solution concentrations $(\mathrm{mg} / \mathrm{L})$ respectively, $\mathrm{V}$ is the volume of IBU solution in litres, $\mathrm{L}$, and $\mathrm{m}$ is mass of carbon adsorbent, g. The IBU removal effectiveness increases with increasing contact time until the equilibrium/saturation capacity on the adsorbent is reached. The quantity of adsorbed IBU on the activated carbon surface rises quickly in the early phase of the process and then decreases continually slowing down, eventually reaching a plateau in the final stage. The duration of the IBU-activated carbon adsorption process to achieve equilibrium was monitored and found to be $12 \mathrm{~h}$. However, the isotherm experiments were continued for a $24 \mathrm{~h}$ cycle to make sure that equilibrium was achieved. The ibuprofen concentration range under investigation varied between 1 to $20 \mathrm{mg} / \mathrm{L}$. quantity of IBU pollutant/solute removed/adsorbed onto the date stone activated carbon adsorbent material, and $\mathrm{C}_{\mathrm{e}}$ $(\mathrm{mg} / \mathrm{L})$, the IBU pollutant/solute remaining in the aqueous phase at equilibrium. For treatment system design purposes, an effective adsorption correlation/model must be developed based on the actual equilibrium experimental data. It is important to test a range of isotherm correlations to determine the most appropriate best fitting isotherm correlation to predict the most accurate design capacity and develop the optimisation equations for both batch and column adsorption processes. In the present study, the experimental data were tested and correlated using seven of the widely accepted isotherm model equations and the best fit parameters were evaluated based on error analyses using the sum of the square of the errors (SSE) method to determine the best fitting equilibrium model and the isotherm constants. The data are presented in Table $\mathbf{3}$ and the isotherm model equations are presented. be independent between adjacent adsorbed species; and finally, the maximum adsorption capacity or saturation

171 capacity takes place due to the adsorbent surface being occupied by a monolayer of the adsorbate species. The 172 amount of adsorbed IBU at the equilibrium point, $\mathrm{q}_{\mathrm{e}}$, is given by equation (4): 
$q_{e}=\frac{q_{m} b_{L} C_{e}}{1+b_{L} C_{e}}$

173

174

175

176

177

178

179

180

181

182

183

184

185

186

187

188

189

190

$\mathrm{q}_{e}, \mathrm{mg}$ IBU/g, is the amount of IBU adsorbed per $\mathrm{g}$ date carbon at equilibrium, $\mathrm{C}_{e}, \mathrm{mg}$ IBU/L solution, is the equilibrium concentration of the IBU adsorbed pharmaceutical in the liquid phase. The constant $q_{m}$ represents the maximum quantity IBU adsorbed in the Langmuir model, and is usually called the monolayer capacity, and b $(\mathrm{L} / \mathrm{mg})$ is the energy the adsorption process, respectively.

To evaluate the Langmuir model constants, Equation (4) can be transposed into the linear expression and is presented in Equation (5):

$\frac{\mathrm{C}_{\mathrm{e}}}{\mathrm{q}_{\mathrm{e}}}=\frac{1}{\mathrm{q}_{\mathrm{m}} \mathrm{bL}}+\frac{\mathrm{C}_{\mathrm{e}}}{\mathrm{q}_{\mathrm{m}}}$

A plot of $\mathrm{q}_{\mathrm{e}}$ versus $\mathrm{C}_{\mathrm{e}}$ for the linearised Langmuir equation format showing the plateau as a point defining the equilibrium monolayer capacity value at which no further adsorption will occur because of the absence of free surface sites.

\subsection{2. $\quad$ Freundlich Isotherm Model}

Freundlich (Freundlich 1906) developed an isotherm correlation to explain the heterogeneous nature and behavior in adsorbents. The Freundlich equation has been widely applied for heterogeneous systems and has been frequently found to explain adsorption of many organic molecules with different interactions onto heterogeneous surface sites. In the Freundlich equation (6) the ratio of the amount of adsorbate adsorbing onto a specific mass of date carbon adsorbent to the IBU solute concentration in solution is not constant with varying increasing adsorbate solution concentrations, that implies, there is no monolayer formation. Freundlich developed this multi-site equilibrium correlation for application to heterogeneous adsorption processes and the mathematical form of this model is shown in equation (6):

$q_{e}=K_{F} C_{e}^{1 / n}$

In equation (6), $\mathrm{q}_{\mathrm{e}}$ is the quantity of IBU adsorbing on the solid date carbon adsorbent at the equilibrium condition $(\mathrm{mg} / \mathrm{g}), \mathrm{C}_{\mathrm{e}}$ is the IBU concentration in solution at equilibrium $(\mathrm{mg} / \mathrm{L}), \mathrm{K}_{\mathrm{F}}$ is the Freundlich coefficient or constant $(\mathrm{L} / \mathrm{g})$ and $1 / \mathrm{n}$ is the Freundlich isotherm exponent. The Freundlich equation is empirical in form and it describes the non-ideal case of adsorption and is logarithmic in nature. It may be used in the case of multilayer adsorption having a non-uniform energy distribution pattern. The quantity of adsorbed material represents the adsorption which occurs at all sites and accounts for the range of individual bond energies. The adsorption energy 
values decrease in an exponential manner until the adsorption step is finished. Consequently, the Freundlich model has proved popular for heterogeneous adsorption, where the potential forces and enthalpies of adsorption are varying along the surface of the adsorbent, and the slope of the linearised equation designates the heterogeneity level; its linear form is shown in equation (7):

$\log q_{e}=\log K_{F}+\frac{1}{n} \log C_{e}$

For this equation, $\mathrm{K}_{\mathrm{F}}(\mathrm{L} / \mathrm{g})$ and $1 / \mathrm{n}$ are indicators of the capacity of the adsorbent and the surface heterogeneity, respectively. The exponential term, $1 / \mathrm{n}$ ranges between 0 , for the more heterogeneous cases, and 1 , for the more homogeneous systems.

\subsubsection{Redlich-Peterson Isotherm Model}

Redlich and Peterson (Redlich and Peterson 1959) developed their three parameter empirical isotherm equation which comprises a numerator term with a linear dependence on $\mathrm{Ce}$, as in the Langmuir model; and an exponential function in the denominator term demonstrating an exponential dependence on $\mathrm{Ce}$, in the form $\mathrm{Ce}^{\mathrm{bR}}$, as isotherms and therefore, the Redlich-Peterson expression in equation (8) represents a hybrid model mechanism.

$q_{e}=\frac{K_{R P} C_{e}}{1+a_{R P} C_{e}^{b R}}$

In equation (8) $\mathrm{q}_{\mathrm{e}}$ and $\mathrm{C}_{\mathrm{e}}$ are defined as previously. $\mathrm{K}_{\mathrm{RP}}$ is the Redlich-Peterson equilibrium constant term (L/g), $a_{R P}$ is an isotherm constant $(\mathrm{L} / \mathrm{mg})$ and $b_{\mathrm{RP}}$ is the Redlich-Peterson exponential parameter, which lies between must fall in the range of 0 to 1 . When $b_{R}=1$, it becomes the Langmuir equation; when $b_{R}=0$, it becomes Henry's law.

\subsubsection{Langmuir-Freundlich or SIPS Isotherm Model}

215 correlation (Sips 1948). Again, this model is a combination comprising the Langmuir and Freundlich expressions to 216 include heterogeneous system mechanisms which are not as extreme than the Freundlich process. The Langmuir217 Freundlich isotherm reduces to the Freundlich equation format at low concentrations, however, moving to higher concentrations, the model, and its parameters approximate more towards the monolayer Langmuir model isotherm.

219 The SIPS or Langmuir-Freundlich isotherm is presented in Equation (9) and substituting for the equilibrium constant, $\mathrm{K}_{\mathrm{LF}}$, equation (10) is obtained: 
$q_{e}=\frac{q_{s} a_{s} C_{e}^{n_{L F}}}{1+a_{s} C_{e}^{n_{L F}}}$

$q_{e}=\frac{K_{L F} C_{e}^{n_{L F}}}{1+a_{L F} C_{e}^{n_{L F}}}$

$\mathrm{C}_{\mathrm{e}}$ and $\mathrm{q}_{\mathrm{e}}$ are defined as before; $\mathrm{q}_{\mathrm{s}}(\mathrm{L} / \mathrm{g})$ and $\mathrm{as}(\mathrm{L} / \mathrm{mg})$ are the Langmuir-Freundlich isotherm capacity and

222 isotherm constant, whereas $\mathrm{K}_{\mathrm{LF}}$ is an equilibrium constant and $\mathrm{n}_{\mathrm{LF}}$ is the isotherm exponent. Also $\mathrm{q}_{\mathrm{s}} \mathrm{a}_{\mathrm{s}}=\mathrm{K}_{\mathrm{LF}}$, the

223 Langmuir-Freundlich equilibrium constant.

$$
q_{e}=\frac{K_{t} C_{e}}{\left(a_{t}+C_{e}^{t}\right)^{1 / t}}
$$

$q_{e}=\left(\frac{R T}{b}\right) \ln \left(K_{T e} C_{e}\right)$

\subsubsection{Temkin Isotherm Model}

The Temkin isotherm was developed to explain hydrogen adsorption during electrolysis in acidic solutions. Consequently, the Temkin isotherm became a preferential isotherm to describe gas-phase equilibrium, but has not been applied much for liquid processes. The Temkin equation assumption is that the heat of adsorption decreases in a linear manner with adsorbate surface coverage as a result of adsorbent/adsorbate interactions (Temkin and Pyzhev 1940). The model is not suitable for the more extreme concentrations both for low and high values. It assumes that the binding energies between the adsorbate and adsorbent are evenly distributed. The Temkin isotherm can be represented by Equations (11) and (12):

$q_{e}=\frac{R T}{b_{T}} \ln K_{T e}+\frac{R T}{b_{T}} \ln C_{e}$

gas constant $(8.314 \mathrm{~kJ} / \mathrm{mol} . \mathrm{K})$ and $\mathrm{T}$ is the absolute temperature at $298 \mathrm{~K}$.

\subsubsection{Toth Isotherm model}

A modification of the Langmuir equation was proposed by Toth (Toth 1971) and comprised a linear Ce dependent term in the numerator in the Langmuir format, and having an exponential term in the denominator as per the Freundlich expression. The Toth modelcan be represented by Equation (13):

Where $\mathrm{K}_{\mathrm{t}}, \mathrm{a}_{\mathrm{t}}$, and $\mathrm{t}$ are Toth constants. 


\subsubsection{Dubinin-Radushkevic Isotherm Model}

Another model, particularly useful for isotherms of a high degree of rectangularity, such as ion exchange, has

241 been developed by Dubinin and Radushkevich. The Dubinin-Radushkevich isotherm (Dubinin 1960) is based on the 242 potential theory and is expressed in equation (14) as:

$q_{e}=q_{s} \exp \left(-B_{D R} \varepsilon^{2}\right)$

243 Where $\varepsilon$ can be expressed as:

$\varepsilon=R \operatorname{Tln}\left(1+\frac{1}{C_{e}}\right)$

Substituting equation (15) into equation (14) produces equation (16):

$q_{e}=q_{m} \exp \left(\frac{\left(R T \ln \left(1+\frac{1}{C_{e}}\right)\right)^{2}}{-2 E^{2}}\right)$

By taking the logarithm of equation (16) yields equation (17):

$\ln q_{e}=\ln q_{s}-B_{D R} R^{2} T^{2}\left[\ln \left(1+\frac{1}{C_{e}}\right)\right]^{2}$

246 and substituting $K_{D B}$ into $B_{D R} R^{2} T^{2}$, equation (14) becomes equation (18):

$\ln q_{e}=\ln q_{s}-K_{B R}\left[\ln \left(1+\frac{1}{C_{e}}\right)\right]^{2}$

$\mathrm{R}$ is the universal gas constant and $\mathrm{T}$ is the absolute temperature; $B_{D R}$ is a constant depending on, $\varepsilon$, the

mean free energy of sorption per adsorbate molecule transferred to the surface of the solid from infinity in the

solution. The free energy is evaluated using equation (15) and $B_{D R}$ is obtained by rearranging equation (19):

$\varepsilon=\frac{1}{\sqrt{2 B_{D R}}}$

\subsection{Error Analysis}

\subsubsection{Sum of Squared Error Analysis Method (SSE)}

The sum of the square of the errors, SSE, is one of the most popular and widely applied error functions by many researchers to evaluate the optimum or best fitting equilibrium relationship correlation (Kumar and Sivanesan 2006) and this SSE method is based on evaluating the sum of the squares for the residuals. The method incorporates both 
the correlation between the experimental and the calculated adsorbed data values and can be expressed by equation

$\operatorname{SSE}=\sum_{\mathrm{i}=1}^{\mathrm{N}}\left(\mathrm{q}_{\mathrm{e}, \exp }-\mathrm{q}_{\mathrm{e}, \mathrm{iso}}\right)_{\mathrm{i}}^{2}$

The subscripts "exp" and "iso" stand for the experimental and calculated adsorbed capacity values, respectively.

The results of the SSE analysis demonstrated that the SIPS, that is, the Langmuir-Freundlich isotherm describes the experimental data extremely accurately. Consequently, the Langmuir-Freundlich model is the preferred equation for application in the adsorbent minimisation model presented in section 3.3.

\subsubsection{Akaike information criterion (AIC)}

The AIC, Akaike information criterion (Akaike 1998), can measure the benefit of a particular isotherm model in comparison with other isotherm model equations, primarily by taking into account the different number of parameters and the relationship is shown in equation (21)

$A I C=2 K-2 \log (L(\hat{\theta} \mid y))$

The lowest of the AIC values, the more superior is the model fitting, where, $\mathrm{K}$ represents the number of estimated parameters and $\log (L(\hat{\theta} \mid y))$ is the $\log$-likelihood value at the maximum point. However, the data set and the same number of points were used in all the models so the AIC analysis is not required as the trend would be the same as the SSE analysis results.

\section{Results and Discussion}

\subsection{Adsorbent Characterization}

A previous TGA study (Hijab et al. 2018) has showed that date stones have a low moisture content, $<10 \%$, and high contents of cellulose and hemicellulose The char experimental yield values were confirmed by the TGA studies, which showed a steady decrease with increasing pyrolysis temperatures, with yields finally reaching about $25 \%$ w/w. Consequently, raw date stones possess considerable potential to be successfully activated, requiring only a small amount of energy for drying. A number of publications have reported the results of activating date stones with various activating agents and at various temperatures (Girgis and El-Hendawy 2002; Merzougui et al. 2011; Suresh Kumar Reddy et al. 2013; Danish et al. 2014; Cherik and Louhab 2017). In order not to duplicate previous work and focus this study on the water treatment application, optimum literature criteria were selected to provide a high surface area at a relatively low temperature for keeping energy costs low. In this study, the date pits were 
281 impregnated with a mass ratio of 2:1 of phosphoric acid to date stone char, activated at $550^{\circ} \mathrm{C}$ for 2 hours with a nitrogen flow of $100 \mathrm{~mL} / \mathrm{min}$. The resulting activated carbon had a yield of $30 \%$, a BET- $\mathrm{N}_{2}$ surface area of 727 $\mathrm{m}^{2} / \mathrm{g}$, a pore volume $0.70 \mathrm{~cm}^{3} / \mathrm{g}$ and a mean pore diameter size $=3.89 \mathrm{~nm}$. The raw date stone possessed a relatively low surface area of $86.0 \mathrm{~m}^{2} / \mathrm{g}$ and a pore volume of $0.22 \mathrm{~cm}^{3} / \mathrm{g}$, proving the beneficial suitability of the activation method.

The BET surface area studies show a similar trend with data retrieved from literature by Girgis and ElHendawy (2002), who obtained the highest surface area using phosphoric acid treated date stone as $740 \mathrm{~m}^{2} / \mathrm{g} . \mathrm{A}$ higher impregnation ratio of 2:1 utilised in this study yielded a similar surface area value. The results of the TGA analysis indicated a moisture content of $8 \%(\mathrm{w} / \mathrm{w})$, a residual solids content of $22 \%(\mathrm{w} / \mathrm{w})$ and the soluble extractive components of $7 \%(\mathrm{w} / \mathrm{w})$. The most rapid and main mass loss occurred at $250^{\circ} \mathrm{C}$ to $350^{\circ} \mathrm{C}$, which was representative of a large percentages of cellulose and hemicellulose. Furthermore, in the region of $400^{\circ} \mathrm{C}, 70 \%$ of the mass has been lost. In the range $400^{\circ} \mathrm{C}$ to $600^{\circ} \mathrm{C}$, the mass loss rate decreased significantly due to the slow breakdown of the large lignin compounds as seen in Table 2 (char yield at various temperatures). Consequently, date stones have demonstrated a strong potential to be successfully applied in activation and pyrolysis.

Table 2. Char yield at different temperatures

\begin{tabular}{cc}
\hline Temperature $(\mathbf{C})$ & Yield $(\boldsymbol{\%})$ \\
\hline 350 & 55.1 \\
\hline 400 & 36.9 \\
\hline 450 & 28.6 \\
\hline 500 & 27.3 \\
\hline 550 & 26.2 \\
\hline 600 & 25.1 \\
\hline
\end{tabular}

The char product yields decrease as the pyrolysis temperature increases. At the lower temperatures, the differences in the product yields are significantly higher. It can be observed that the extent of mass loss decreased with increasing temperature and is much lower at the high temperatures because of the large lignin molecules which are difficult to fracture.

\subsection{Equilibrium studies}

The Langmuir-Freundlich or SIPS isotherm provides the best correlation to the experimental equilibrium data values based on the SSE and correlation coefficient $\left(\mathrm{R}^{2}\right)$ values in Table 3. The type of isotherm gives an indication regarding the type and nature of the adsorption mechanism. In the case of phosphoric acid treated date stone chars, 
in this study, the SIPS or Langmuir-Freundlich is the best fit equilibrium isotherm. The Freundlich and Tempkin isotherm equations were excluded for the remainder of the analysis due to their large SSE values. The Langmuir model is based on monolayer adsorbate coverage so that the isotherm reaches a plateau, when the maximum equilibrium capacity is achieved, and when the adsorption stage takes place on one kind of surface site only, which all have an equal adsorption energy. The Langmuir-Freundlich model indicates the variance on this mechanism, showing some degree of heterogeneous adsorption, but still the site energy levels are similar. The two curves in

312 Figure 1 indicate the formation of a plateau by the last few high concentration data values showing the date stone derived activated carbon has achieved saturation. The results show a significant increase in the capacity of IBU adsorption onto date stones after the phosphoric acid treatment. The maximum IBU adsorption capacity for the phosphoric acid activated date stone carbon is $126 \mathrm{mg} / \mathrm{g}$ based on the Langmuir isotherm, extrapolating the experimental data also provides a value of $125 \pm 3 \mathrm{mg} / \mathrm{g}$, and the best fit Langmuir-Freundlich isotherm also yields a capacity value of $126 \mathrm{mg} / \mathrm{g}$. Therefore this is the maximum adsorption capacity used in further discussions and the design modelling.

Table 3. Isotherm Parameters and SSE of IBU adsorption on date stone activated carbon

\begin{tabular}{|c|c|c|c|c|c|c|c|}
\hline & Langmuir & Freundlich & Temkin & DR & $\begin{array}{l}\text { Redlich- } \\
\text { Peterson }\end{array}$ & SIPS/ LF & Toth \\
\hline SSE & 42.1 & 72.3 & 317.0 & 727.0 & 33.0 & 25.0 & 30.0 \\
\hline Parameter & $\begin{array}{l}\mathrm{K}_{\mathrm{L}}=19.0 \\
\mathrm{a}_{\mathrm{L}}=0.151 \\
\mathrm{q}_{\mathrm{m}}=126\end{array}$ & $\begin{array}{l}\mathrm{K}_{\mathrm{F}}=22.0 \\
\mathrm{n}_{\mathrm{F}}=1.91\end{array}$ & $\begin{array}{l}\mathrm{B}=2.74 \\
\mathrm{~A}_{\mathrm{T}}=112\end{array}$ & $\begin{array}{l}Q_{m}=83.4, \\
E=550\end{array}$ & $\begin{array}{l}\mathrm{K}_{\mathrm{RP}}=27.6, \\
\mathrm{a}_{\mathrm{RP}}=0.428, \\
\mathrm{~b}_{\mathrm{RP}}=0.776\end{array}$ & $\begin{array}{l}\mathrm{K}_{\mathrm{LF}}=16.4, \\
\mathrm{n}_{\mathrm{LF}}=1.24, \\
\mathrm{a}_{\mathrm{LF}}=0.130\end{array}$ & $\begin{array}{l}\mathrm{Q}_{\mathrm{m}}=216 \\
\mathrm{~K}_{\mathrm{T}}=2.84 \\
\mathrm{n}=0.552\end{array}$ \\
\hline
\end{tabular}




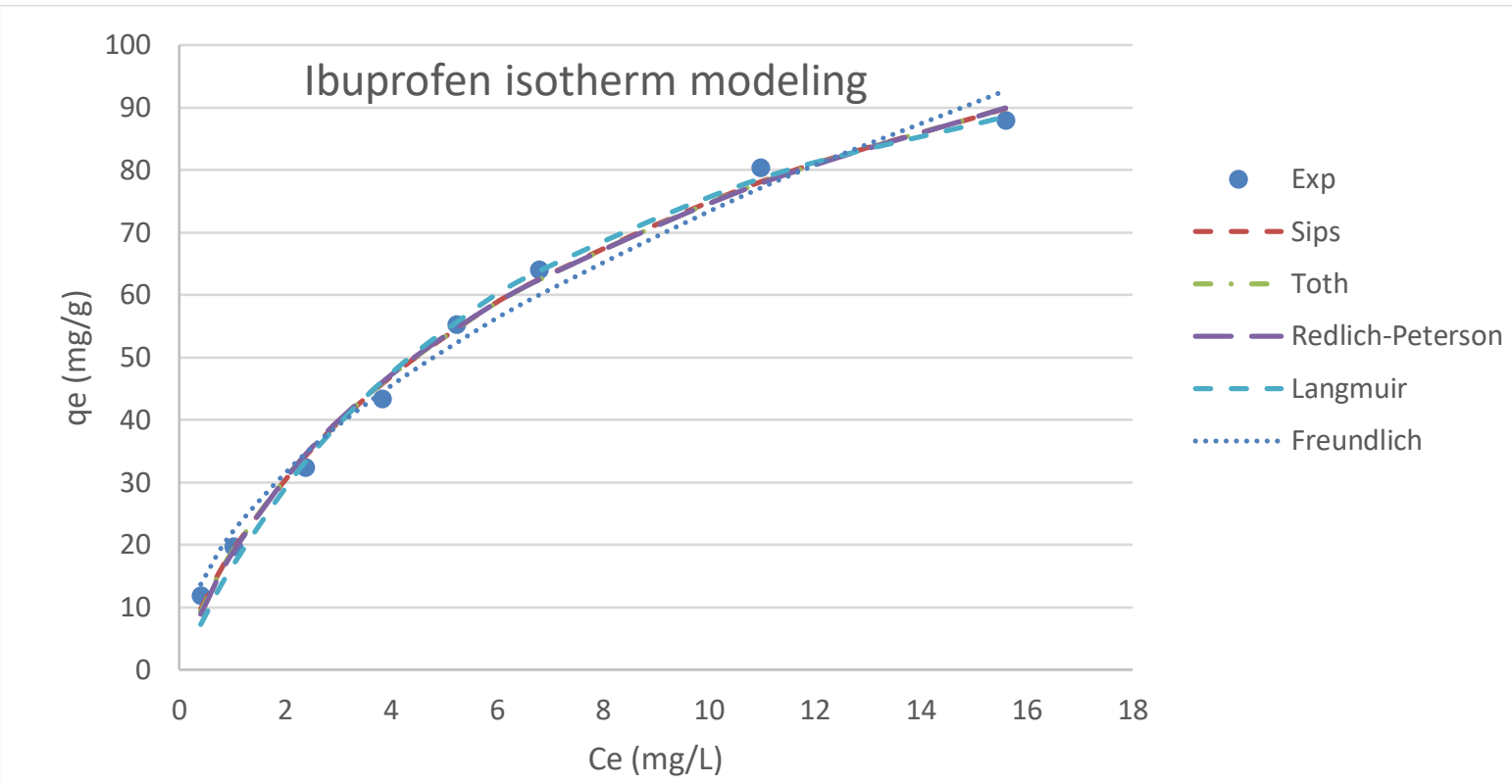

Figure 1. Five isotherm models compared with the experimental IBU equilibrium data.

Other studies (see Table 4.) for the adsorption of IBU using various adsorbents obtained a wide range of capacities; for carbide derived carbon (Almanassra et al. 2020), commercial activated carbon (Guedidi et al. 2013) and olive waste cake derived activated carbon (Baccar et al. 2012) the IBU adsorption capacities were 367, 160 and $14.4 \mathrm{mg} \mathrm{IBU/g}$ adsorbent. Two of the values are very high but they were performed at very acidic $\mathrm{pH}$ to optimise the capacity. In practice, the effluents and treated sewage waters, where these emerging pollutants are prominent generally have $\mathrm{pH}$ values in the range of 6 to 8.5. The capacity of our phosphoric acid activated date stone carbon at $64.7 \mathrm{mg} / \mathrm{g}$, is lower, but still in the same range of magnitude but the treatment process was performed at a pH value of 7.

Table 4. IBU adsorption capacities on various materials

\begin{tabular}{lllllll}
\hline Adsorbent & $\begin{array}{l}\text { Surface } \\
\text { area } \\
\left(\mathbf{m}^{2} / \mathbf{g}\right)\end{array}$ & Isotherm & $\begin{array}{l}\text { Equilibrium } \\
\text { time }(\mathbf{h})\end{array}$ & $\begin{array}{l}\text { IBU } \\
\text { concentration } \\
(\mathbf{m g} / \mathbf{L})\end{array}$ & $\begin{array}{l}\text { Maximum IBU } \\
\text { adsorption } \\
\text { capacity } \\
(\mathbf{m g} / \mathbf{g})\end{array}$ & Ref. \\
\hline $\mathrm{CDC}$ & 1054 & Langmuir & 24 & $1-20$ & 367 at pH 3, & $\begin{array}{l}\text { (Almana } \\
\text { ssra et } \\
\text { al. }\end{array}$ \\
& & & & $293 \mathrm{~K}$ & $2020)$ \\
\hline $\begin{array}{l}\text { Commercial } \\
\text { granular AC }\end{array}$ & 800 & $\begin{array}{l}\text { Langmuir- } \\
\text { Freundlich }\end{array}$ & 67 & $5-100$ & 160 at pH 3, & $\begin{array}{l}\text { (Guedid } \\
\text { i et al. }\end{array}$ \\
\hline $\begin{array}{l}\text { Olive waste } \\
\text { cake AC }\end{array}$ & 793 & Langmuir & 26 & & $298 \mathrm{~K}$ & $2013)$ \\
\hline
\end{tabular}


Our optimisation study is based on minimising the amount of activated date stone carbon adsorbent using a twostage batch process represented in the schematic in Figure 2. The IBU capacities will be determined using the best

339 fit equilibrium isotherm for the phosphoric acid treated date stone activated carbon, and the concentration, Ce, or $\mathrm{C}_{2}$,

340 is the IBU concentration in the treated effluent, to be discharged from the two-stage process. Typically this concentration value is important because it is the maximum or effluent pollutant concentration limit allowed by the

342 legislative authorities in their effluent discharge limits for process licensing to be allowed into receiving waters. It is 343 of the utmost importance to determine the adsorbent IBU uptake capacity at this $C_{e} / C_{2}$ value - because it is this capacity that is controlling the quantity of adsorbent required in the operating wastewater facility. It is almost certain that this corresponding $\mathrm{q}_{\mathrm{e}}$ value will not correspond to the maximum isotherm adsorption capacity, $\mathrm{q}_{\max }$, because its value is determined by $\mathrm{C}_{2}$ and the system operating line gradient. The isotherm equation representing the adsorbate uptake mass balance, provides the corresponding adsorption capacity value at $\mathrm{C}_{2}$. Consequently, it becomes of great significance to evaluate this design capacity at the plant design stage, because the mass of adsorbent will be less than the $\mathrm{q}_{\mathrm{e}, \mathrm{max}}$ capacity and therefore the adsorber plant units sizes will need to be increased . typically utilized for the removal of pollutants produced by industrial operations at a relatively small scale. However, the application of single-stage batch adsorption processes has difficulty meeting the required legislative effluent

354 limit discharge value, although the single-stage batch operation is highly flexible. This is due to the stringent and 355 steadily intensifying final low level discharge concentrations imposed by the environmental legislation authorities,

356 because it implies very large quantities of the adsorbent, as shown later in this study. The system modelling for the 357 two-stage batch adsorber is now presented. The process schematic for the two-stage batch adsorber unit is presented in Figure 2. 


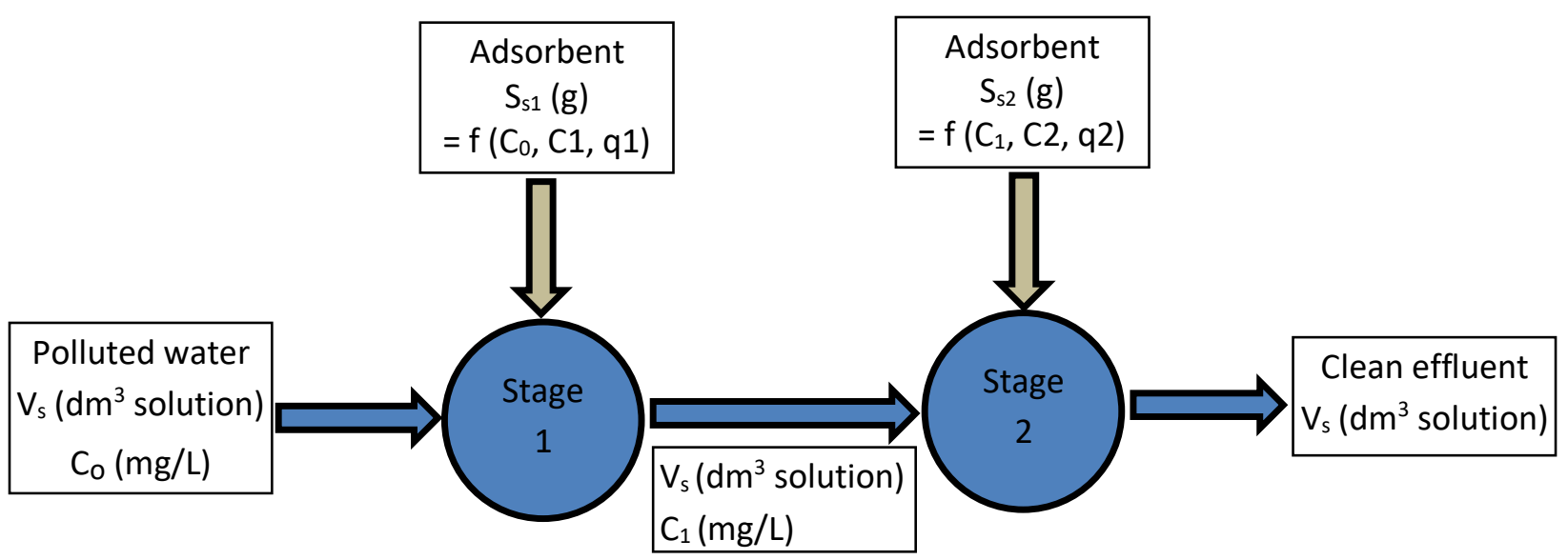

Figure 2. Schematic figure of a two-stage system

A two-stage adsorption scheme is presented in Figure 2, showing $S_{\mathrm{s} 1}$ and $S_{\mathrm{s} 2}$ are the quantities of the adsorbent in each adsorber vessel, namely, stage 1 and stage 2 respectively; hence, the total date stone carbon adsorbent, which is required, is $S_{\mathrm{s} 1}+S_{\mathrm{s} 2}$. To estimate the minimum total quantity adsorbent to be applied for achieving the final effluent discharge concentration leaving stage 2, that is $\mathrm{C}_{2}$. Then, it is required to minimize this quantity, namely, $S_{\mathrm{s} 1}+S_{\mathrm{s} 2}$, and this value may be obtained from, $d\left(S_{\mathrm{s} 1}+\mathrm{S}_{\mathrm{s} 2}\right) \mathrm{Vs}_{\mathrm{s}} / \mathrm{dC}_{1}$ and equating to zero to for the maximum or minimum values. The derived solution equation then provides the interstage intermediate concentration, $\mathrm{C}_{1}$, to be obtained; and using this value, the two adsorbers required carbon quantities can be determined using equations (22) and (24).

Using the most accurate isotherm correlation, namely, Langmuir-Freundlich, as being the best fit isotherm,

$\frac{S_{s 1}}{V_{s}}=\frac{C_{0}-C_{1}}{q_{1}-q_{0}}$

$\frac{S_{S 1}}{V_{S}}=\frac{\left(C_{0}-C_{1}\right)\left(1+a_{L F} C_{1}^{b_{L F}}\right)}{K_{L F} C_{1}^{b_{L F}}}$

For the stage 2 adsorber unit, represented by equation (24):

$\frac{S_{s 2}}{V_{s}}=\frac{C_{1}-C_{2}}{q_{2}-q_{0}}$

By an analogous substitution as before, but for $\mathrm{q}_{2}$, then equation (24) becomes equation (25): 
$\frac{S_{s 2}}{V_{s}}=\frac{\left(C_{1}-C_{2}\right)\left(1+a_{L F} C_{2}^{b_{L F}}\right)}{K_{L F} C_{2}^{b_{L F}}}$

The total amount of adsorbent used is given by equation (26):

$$
\frac{S_{S 1}+S S_{2}}{V_{S}}=\frac{1}{K_{L F}}\left(\frac{\left(C_{0}-C_{1}\right)\left(1+a_{L F} C_{1}^{b_{L F}}\right)}{C_{1}^{b_{L F}}}+\frac{\left(C_{1}-C_{2}\right)\left(1+a_{L F} C_{2}^{b_{L F}}\right)}{C_{2}^{b_{L F}}}\right)
$$

Now this differential term,

$378 \frac{d\left[\left(S_{S 1}+S_{S 2}\right) / V_{S}\right]}{d C_{1}}$ is set equal to zero in order to determine the minimum total adsorbent required. Rearranging, and 379 (26) becomes equation (27):

$0=\frac{1}{K_{L F}}\left[\frac{b_{L F}-1}{C_{1}^{b_{L F}}}-\frac{b_{L F} C_{0}}{C_{1}^{b_{L F}+1}}+\frac{1}{C_{2}^{b_{L F}}}\right]$

Multiplying by $C_{1}^{b_{L F}}$ and rearranging, produces equation (28):

$0=\left(\frac{C_{1}}{C_{2}}\right)^{b_{L F}}-b_{L F}\left(\frac{C_{0}}{C_{1}}-1\right)-1$

The intermediate concentration, $\mathrm{C}_{1}$, may be evaluated by solving Equation (28) and applying the Microsoft

Excel solver function. Consequently, the optimised value for the minimum quantity of date stone activated carbon

required for each unit can be obtained using Equations (23) and (25). In section 4.4, various limitations for the extent of IBU removal have been applied as percentage removal and also in terms of absolute final concentrations of

IBU in the effluent, eg. similar to fixing effluent limit discharge values. This allows the eventual comparison of the quantity of date stone carbon required for the single stage process with the amount required for a two-stage adsorber in section 4.5.2. This adsorbent quantification has been undertaken to evaluate the optimised minimum adsorbent amounts for the phosphoric acid treated date stone.

\subsection{Model Results and Discussion}

The first target was to assess the amount of phosphoric acid treated date stone carbon required in order to 391 achieve the final discharge limit values in terms of percentage removals of IBU for $0.5 \% \mathrm{C}_{0}, 1 \% \mathrm{C}_{0}, 2 \% \mathrm{C}_{0}$, and $5 \% \mathrm{C}_{0}$; and the second target was to determine the quantities of this carbon necessary to achieve certain fixed set

393 discharge concentration limits of IBU to meet the set values of $0.5,1,2$ and $5 \mathrm{mg} / \mathrm{g}$, have been analyzed. The 394 Langmuir-Freundlich (Sips) isotherm parameters, as the best fitting equation data, were applied for modelling the process optimization and minimizing the quantity of the acid activated date stone carbon, which was used in the 
model to optimize the system by minimizing the total date carbon to be used. Table $\mathbf{5}$ is the summary of the optimized amounts of the acid activated date carbon required when the final effluent concentration of IBU is $0.5 \%$ of the initial concentration, $\mathrm{C}_{0}$. The tables for the other four percentages are presented in the Supplementary Information tables $\mathbf{S . 1}$ for $5.0 \% \mathrm{C}_{0}, \mathbf{S . 2}$ for $2.0 \% \mathrm{C}_{0}$ and $\mathbf{S . 3}$ for $1.0 \% \mathrm{C}_{0}$.

400

401 402

Table 5. Minimum total quantity of phosphoric acid treated date stone activated carbon to remove IBU using the Langmuir-Freundlich model to achieve $\mathrm{C}_{2}=0.5 \% \mathrm{C}_{0}$ for $1000 \mathrm{~L}$ of solution

\begin{tabular}{cccccc}
\hline $\mathbf{C}_{\mathbf{0}}(\mathbf{m g} / \mathbf{L})$ & $\mathbf{C}_{\mathbf{2}}(\mathbf{m g} / \mathbf{L})$ & $\mathbf{C}_{\mathbf{1}}(\mathbf{m g} / \mathbf{L})$ & $\mathbf{S}_{\mathbf{s} \mathbf{1}}(\mathbf{k g})$ & $\mathbf{S}_{\mathbf{s} 2}(\mathbf{k g})$ & $\mathbf{S}_{\mathbf{s} \mathbf{1}}+\mathbf{S}_{\mathbf{s} 2}(\mathbf{k g})$ \\
\hline 1 & 0.005 & 0.084 & 1.19 & 3.41 & 4.60 \\
2 & 0.010 & 0.169 & 1.02 & 2.88 & 3.90 \\
3 & 0.015 & 0.253 & 0.931 & 2.62 & 3.55 \\
4 & 0.020 & 0.337 & 0.880 & 2.45 & 3.32 \\
5 & 0.025 & 0.421 & 0.841 & 2.32 & 3.16 \\
6 & 0.030 & 0.506 & 0.813 & 2.22 & 3.03 \\
7 & 0.035 & 0.590 & 0.792 & 2.14 & 2.93 \\
8 & 0.040 & 0.674 & 0.776 & 2.07 & 2.85 \\
10 & 0.050 & 0.843 & 0.753 & 1.97 & 2.72 \\
12 & 0.060 & 1.012 & 0.738 & 1.88 & 2.62 \\
14 & 0.070 & 1.180 & 0.728 & 1.82 & 2.54 \\
15 & 0.075 & 1.264 & 0.725 & 1.79 & 2.51 \\
16 & 0.080 & 1.349 & 0.723 & 1.76 & 2.48 \\
18 & 0.090 & 1.517 & 0.720 & 1.71 & 2.43 \\
20 & 0.100 & 1.686 & 0.719 & 1.67 & 2.39 \\
\hline
\end{tabular}




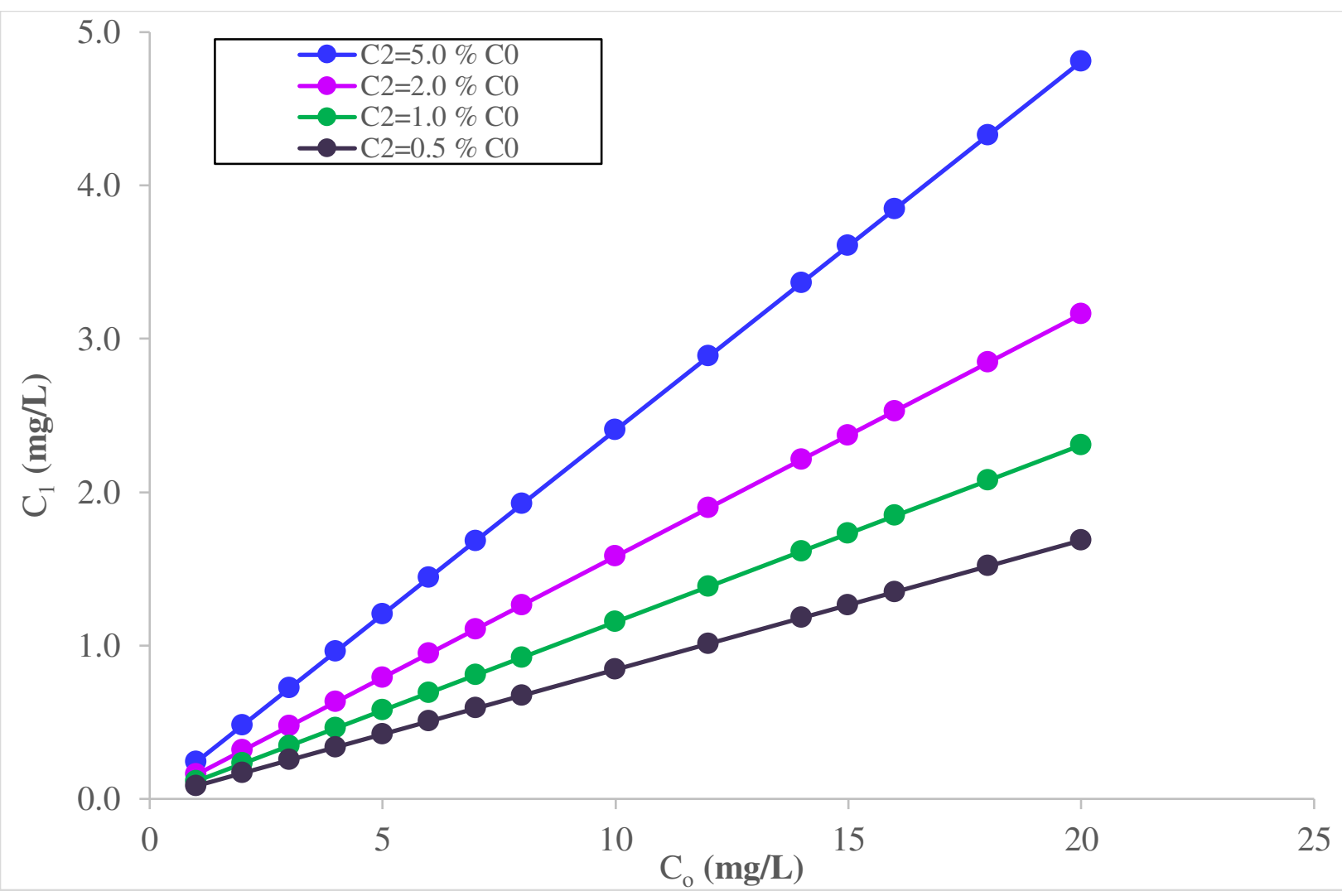

Figure 3. Interstage concentrations, $\mathrm{C} 1$, to remove different fixed $\% \mathrm{C}_{0} \mathrm{IBU}$ using the Langmuir-Freundlich model.

In Table 5, it cab be observed that more date stone activated carbon is required for the second stage adsorber,

$412 \mathrm{~S}_{2}$, than in the case of the first adsorber stage, $\mathrm{S}_{1}$. For example at Co $=1 \mathrm{mg} / \mathrm{L}$ and the removal target is $0.05 \% \mathrm{C}_{0}$, then $S_{1}=1192 \mathrm{~g}$ and $S_{2}=3408 \mathrm{~g}$. In all the cases tested, the ratio of the adsorbent used, namely, $S_{2}: S_{1}$ is in the range of 2.0 to 2.5 . Furthermore, for the same initial concentrations the target $\% \mathrm{C} 0$ removal significantly affects the total quantity of date carbon required. This requirement occurs because the final concentration, C2, required to be achieved is steadily increasing as the $\% \mathrm{C} 0$ increases; therefore, the percentage change in the $\mathrm{C} 2$ discharge is also

417 being relaxed as $\mathrm{C} 2$ is allowed to increase. Consequently, the percentage decrease requirement in the IBU 418 concentration is larger in the first condition (total carbon requirement $=4600 \mathrm{~g}$ adsorbent for $0.5 \% \mathrm{C} 0$ at $\mathrm{C}_{0}=1$ $\mathrm{mg} / \mathrm{L}$ ); than that in the second condition (total carbon requirement $=2700 \mathrm{~g}$ adsorbent for $1.0 \% \mathrm{C} 0$ at $\mathrm{C}_{0}=1 \mathrm{mg} / \mathrm{L}$ ); and third stage (total carbon requirement $=1570 \mathrm{~g}$ adsorbent for $2.0 \% \mathrm{C} 0$ at $\mathrm{C}_{0}=1 \mathrm{mg} / \mathrm{L}$ ); and finally the fourth

421 condition (total carbon requirement $=746 \mathrm{~g}$ adsorbent for $5.0 \% \mathrm{C} 0$ at $\mathrm{C}_{0}=1 \mathrm{mg} / \mathrm{L}$ ); as the $\%$ Co increases therefore 422 allowing an increase in $\mathrm{C} 2$ and consequently, relaxing on the total amount of adsorbent needed. The trend is seen in 
423 Figure 3 for the four \% Co changes at a range of $\mathrm{C}_{0}$ values. The variation in the total adsorbent quantity required as

424 a function of the intermediate concentration, $\mathrm{C}_{1}$, between the two stages, is shown in Figure 4 . It is interesting to 425 note that there is a levelling out in the total adsorbent mass required at each $\% \mathrm{C}_{0}$ target discharge level at around $\mathrm{C}_{1}$

$426=2 \mathrm{mg} / \mathrm{L}$.

427

428

429

430

431

432

433

434

435

436

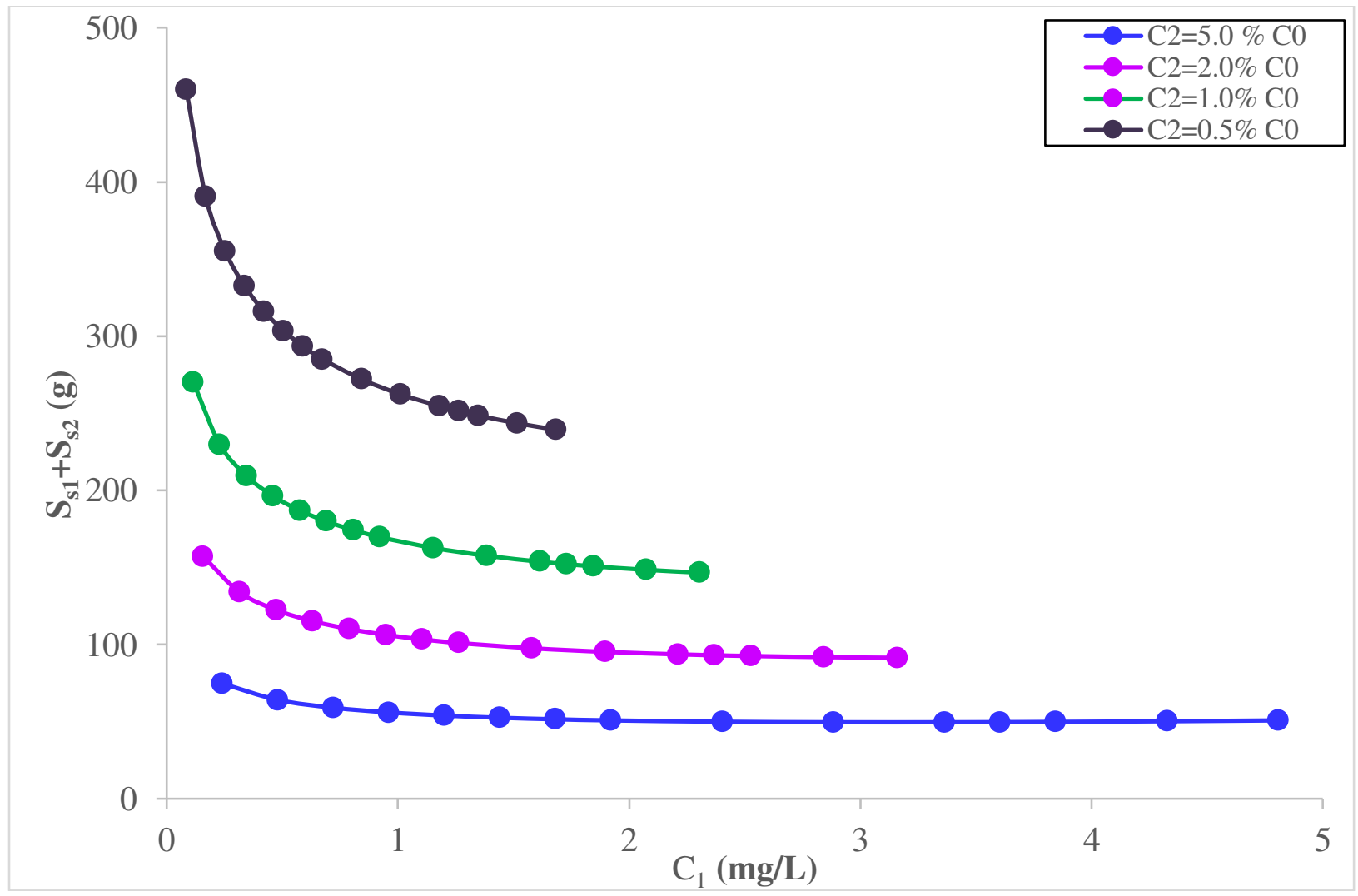

Figure 4. Minimum quantity of acid treated date stone activated carbon, $S_{1}+S_{2}$, against the interstage concentrations, $\mathrm{C}_{1}$, to remove IBU using the Langmuir-Freundlich model for different removal values, $\% \mathrm{C} 0$.

A further correlation of particular interest to the water treatment plant design engineer is the relationship between the total quantity of date carbon required and the initial concentration, $\mathrm{C}_{0}$, of the pollutant material. Figure 5 presents the curves for the present system of $\mathrm{S} 1+\mathrm{S} 2$ against $\mathrm{C}_{0}$ for the range of final discharge levels based on $\%$ $\mathrm{C}_{0}$ for IBU removal using the waste date stone derived activated carbon. Again the figure shows an interesting trend by levelling out at relatively constant fixed adsorbent quantities at $\mathrm{C}_{0}=10 \mathrm{mg} / \mathrm{L}$ at the individual $\% \mathrm{C}_{0}$ removal values. 


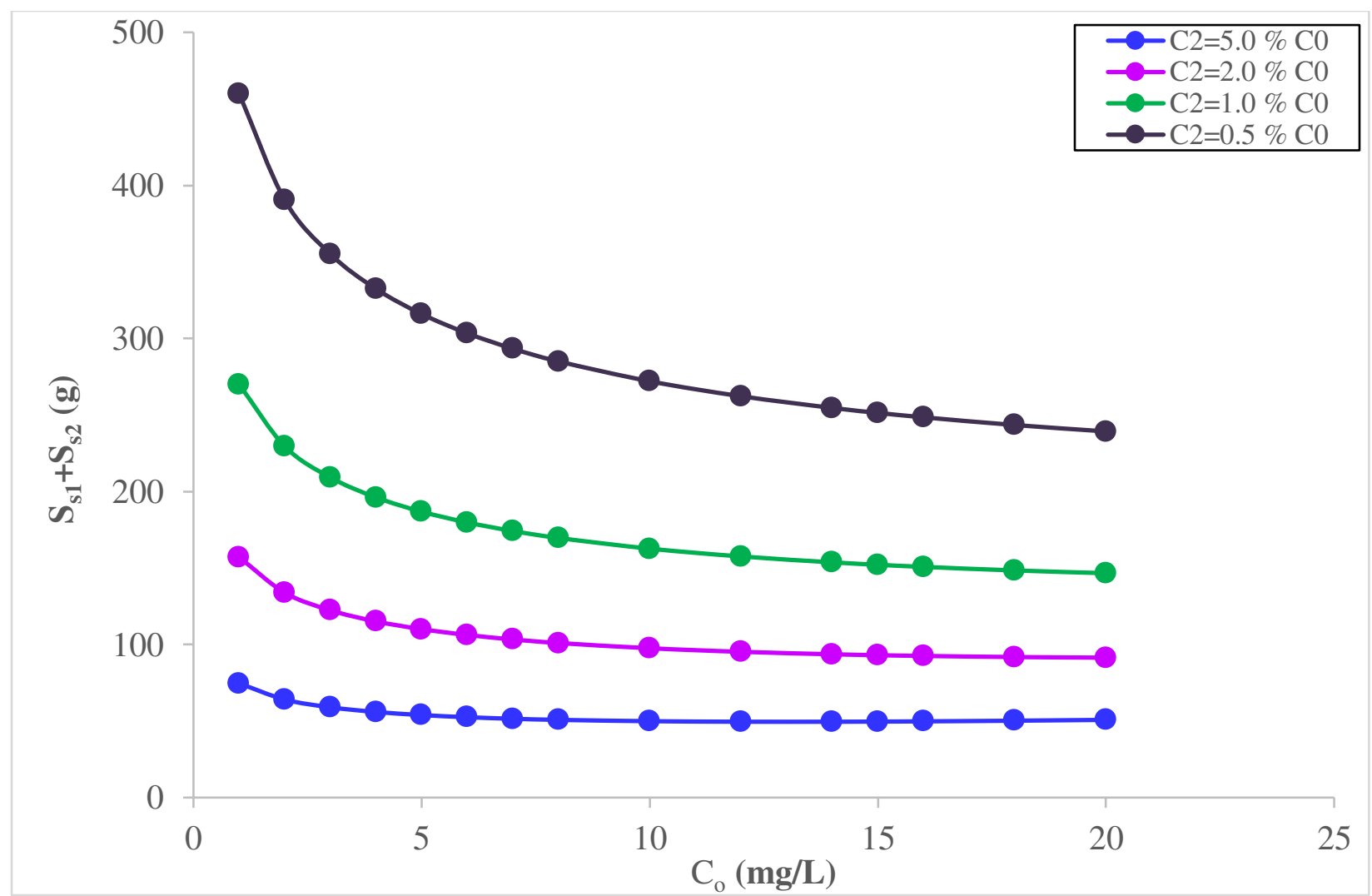

Figure 5. Minimum total quantity of acid treated date stone activated carbon, $S_{1}+S_{2}$, against the initial IBU concentration, $\mathrm{C}_{0}$, to remove a fixed $\% \mathrm{C}_{0}$ IBU using the Langmuir-Freundlich model.

Table 6 summarises the optimum amounts of the date acid activated carbon $\left(S_{1}+S_{2}\right)$ neede to achieve a final effluent concentration, $\mathrm{C}_{2}$, when the $\mathrm{C}_{2} \mathrm{IBU}$ is $0.20 \mathrm{mg} / \mathrm{L}$ for a range of initial IBU concentrations from $\mathrm{C}_{0}=1.0$ to $20 \mathrm{mg} / \mathrm{L}$. The tables for the other three specified final discharge concentrations, namely, $\mathrm{C}_{2}=0.10,0.050$ and 0.10 $\mathrm{mg} / \mathrm{L}$ concentrations percentages are presented in the Supplementary Information tables $\mathbf{S . 4}$ for $0.5 \% \mathrm{C}_{0}, \mathbf{S . 5}$ for $0.20 \mathrm{mg} / \mathrm{L}$, and $\mathbf{S . 6}$ for $0.10 \mathrm{mg} / \mathrm{L}$. The trends in Table $\mathbf{6}$ and the Supplementary Information files are similar to the general trends in Table 5 and its associated but with different individual amounts of date carbon adsorbent requirements. All the data values are plotted in Figure 6 to enable a comparison due to the effect of the initial discharge concentration $\mathrm{C} 0$ and its influence on the mass of adsorbent required for a fixed final treated effluent discharge concentration of $0.20 \mathrm{mg} / \mathrm{L}$.

Table 6. Minimum total quantity of date stone acid treated activated carbon to remove IBU using the LangmuirFreundlich model to achieve $\mathrm{C}_{2}=0.20 \mathrm{mg} / \mathrm{L}$

\begin{tabular}{cccccc}
\hline $\mathbf{C}_{\mathbf{0}}(\mathbf{m g} / \mathbf{L})$ & $\mathbf{C}_{\mathbf{2}}(\mathbf{m g} / \mathbf{L})$ & $\mathbf{C}_{\mathbf{1}}(\mathbf{m g} / \mathbf{L})$ & $\mathbf{S}_{\mathbf{s} \mathbf{1}}(\mathbf{k g})$ & $\mathbf{S}_{\mathbf{s} 2}(\mathbf{k g})$ & $\mathbf{S}_{\mathbf{s} 1}+\mathbf{S}_{\mathbf{s} 2}(\mathbf{k g})$ \\
\hline 1 & 0.20 & 0.458 & 0.089 & 0.117 & 0.206
\end{tabular}




\begin{tabular}{cccccc}
2 & 0.20 & 0.663 & 0.145 & 0.209 & 0.353 \\
3 & 0.20 & 0.824 & 0.184 & 0.281 & 0.465 \\
4 & 0.20 & 0.962 & 0.216 & 0.343 & 0.559 \\
5 & 0.20 & 1.085 & 0.244 & 0.399 & 0.643 \\
6 & 0.20 & 1.197 & 0.269 & 0.450 & 0.718 \\
7 & 0.20 & 1.302 & 0.292 & 0.497 & 0.789 \\
8 & 0.20 & 1.400 & 0.313 & 0.541 & 0.854 \\
10 & 0.20 & 1.580 & 0.353 & 0.622 & 0.975 \\
12 & 0.20 & 1.745 & 0.389 & 0.690 & 1.09 \\
14 & 0.20 & 1.898 & 0.423 & 0.766 & 1.19 \\
15 & 0.20 & 1.971 & 0.440 & 0.799 & 1.24 \\
16 & 0.20 & 2.042 & 0.455 & 0.831 & 1.29 \\
18 & 0.20 & 2.178 & 0.486 & 0.892 & 1.38 \\
20 & 0.20 & 2.307 & 0.516 & 0.950 & 1.47 \\
\hline
\end{tabular}

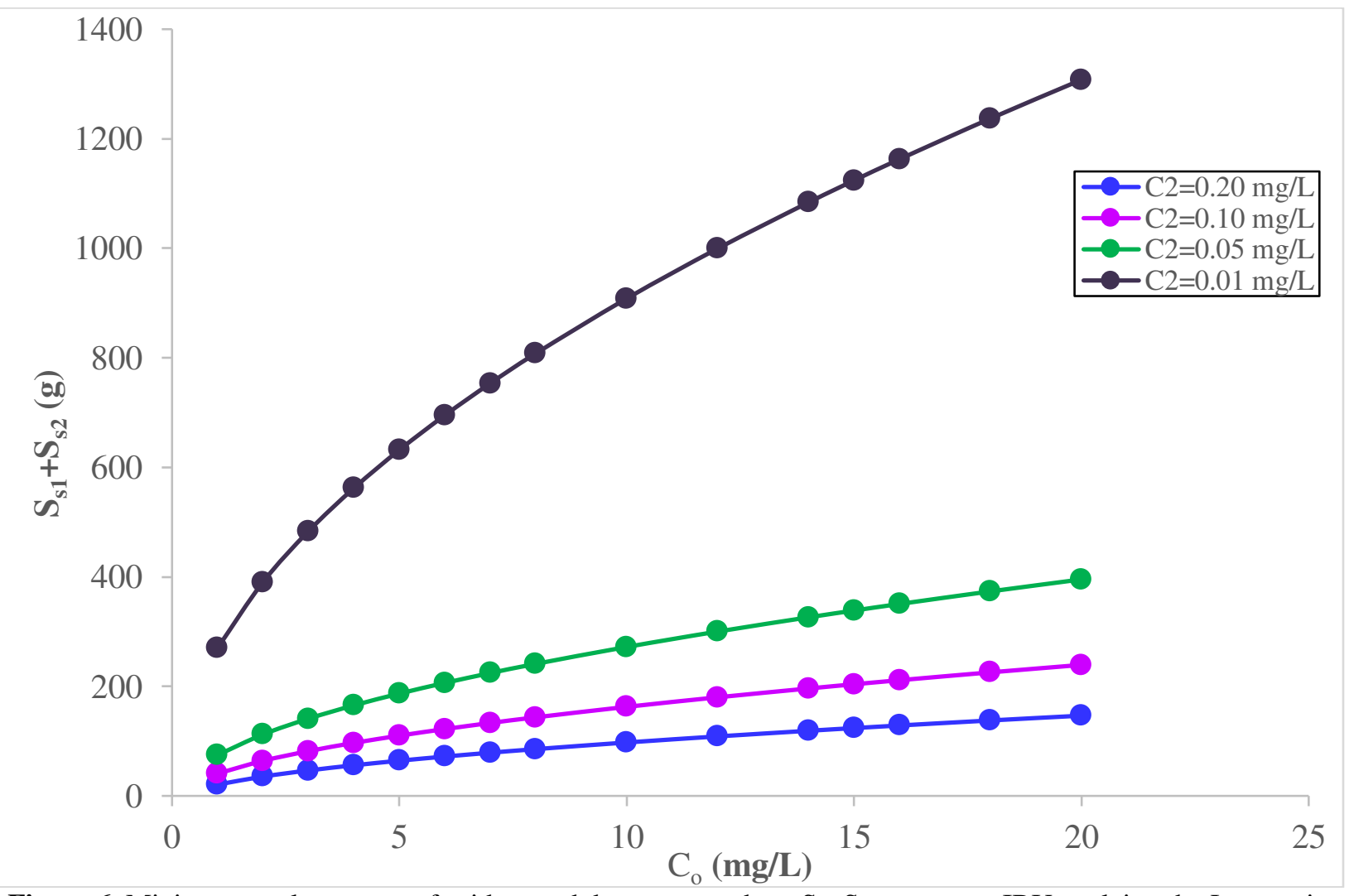

Figure 6. Minimum total quantuty of acid treated date stone carbon, $\mathrm{S}_{1}+\mathrm{S}_{2}$, to remove IBU applying the LangmuirFreundlich model at different initial IBU concentrations, $\mathrm{C}_{0}$, for different set values of final IBU concentrations, $\mathrm{C}_{2}$, in the effluent

In Figure 6, the required total quantity of date activated carbon increases either with increasing initial IBU concentration or with the lower the IBU concentration in the final solution discharge, $\mathrm{C}_{2}$. The optimization results 
for the total quantity of acid treated date stone carbon for removing the IBU to comply with certain set values of $\mathrm{C}_{2}$

462

463

provides an important reference point, for example, when there is a legislative or imposed effluent discharge standard for treating the effluent, containing IBU, that must be achieved.

Inspection of Table 6, shows that more adsorbent is needed for the second stage adsorber, S2, than for the first stage adsorber, S1, for example at Co $=10 \mathrm{mg} / \mathrm{L}$ and the removal target is $0.20 \mathrm{mg} / \mathrm{L}$, then $\mathrm{S} 1=353.0 \mathrm{~g}$ and S2 $=622.5 \mathrm{~g}$. In all the cases tested, the ratio of the adsorbent used, namely, S2:S1 is in the range of 1.4 to 2.0. Furthermore, for the same initial concentrations the discharge concentration, $\mathrm{C}_{2}$, significantly affects the total quantity of date carbon required. This requirement occurs because the final discharge concentration, $\mathrm{C}_{2}$, is decreasing from 0.20 to $0.01 \mathrm{mg} / \mathrm{L}$ and the total amount of adsorbent required is steadily increasing as $\mathrm{C}_{2}$ is decreasing. Consequently, the change/decrease taking place in the IBU concentration $\left(\mathrm{C}_{0}-\mathrm{C}_{2}\right)$ at a set $\mathrm{C}_{0}$ is lowest for the highest $\mathrm{C}_{2}$ (total carbon requirement $=975.5 \mathrm{~g}$ adsorbent for $\mathrm{C}_{2}=0.20 \mathrm{mg} / \mathrm{L}$ at $\mathrm{C}_{0}=10 \mathrm{mg} / \mathrm{L}$ ); and in the second highest initial concentration (total carbon requirement $=1626.2 \mathrm{~g}$ adsorbent for $\mathrm{C}_{2}=0.10 \mathrm{mg} / \mathrm{L}$ at $\mathrm{C}_{0}=10 \mathrm{mg} / \mathrm{L}$ ); and the third highest value of $\mathrm{C}_{2}=0.05 \mathrm{mg} / \mathrm{L}$ (total carbon requirement $=2720.0 \mathrm{~g}$ adsorbent for $\mathrm{C}_{2}=0.05 \mathrm{mg} / \mathrm{L}$ at $\mathrm{C}_{0}=10 \mathrm{mg} / \mathrm{L}$ ); and finally the fourth and lowest discharge condition of $\mathrm{C}_{2}=0.01 \mathrm{mg} / \mathrm{L}$ and requiring the highest mass at this (total carbon requirement $=9082.1 \mathrm{~g}$ adsorbent for $\mathrm{C}_{2}=0.05 \mathrm{mg} / \mathrm{L}$ at $\mathrm{C}_{0}=10 \mathrm{mg} / \mathrm{L}$ ); as the $\mathrm{C}_{2}$ design value decreases, therefore an increase in the total adsorbent mass, $S_{1}+S_{2}$, is required. The trend is seen in Figure 5 for the four $\mathrm{C}_{2}$ changes at a range of $\mathrm{C}_{0}$ values.

The variation in the total adsorbent quantity required as a function of the interstage concentration, $\mathrm{C}_{1}$, between the two stages, is shown in Figure 7, for the four different set effluent IBU discharge values for the final IBU concentrations in the effluent, $\mathrm{C}_{2}$. It is interesting to observe that there is an almost linear trend in the total adsorbent mass required at each $\mathrm{C}_{2}$ discharge level value. the minimum total quantity of acid treated date stone, $\mathrm{S}_{1}+\mathrm{S}_{2}$, to remove IBU against the interstage IBU concentration, $\mathrm{C}_{1}$, using the Langmuir-Freundlich model for the four different fixed IBU permitted discharge concentration values in the final effluent, $\mathrm{C}_{2}$. 


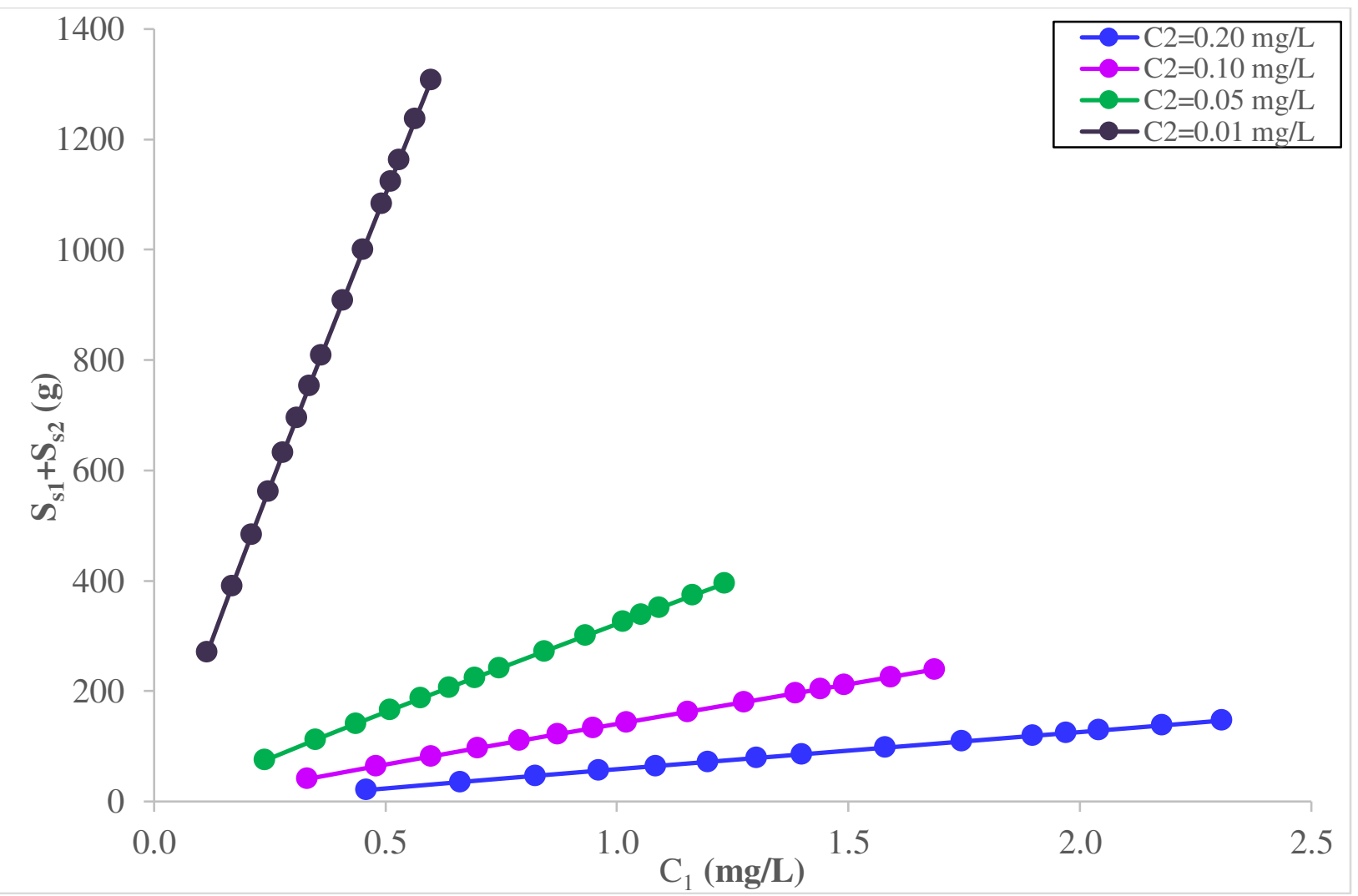

Figure 7. Minimum quantity of acid treated date stone carbon, $S_{1}+S_{2}$, to remove IBU against the interstage IBU concentration, $\mathrm{C}_{1}$, using the Langmuir-Freundlich model for the set values of final IBU concentrations in the effluent, $\mathrm{C}_{2}$.

Figures 3 to 7 .

493 Figure 7 shows interstage concentrations, $\mathrm{C}_{1}$, for acid treated date stone carbon to remove IBU using the Langmuir-

494 Freundlich model for different initial IBU concentrations, $\mathrm{C}_{0}$, for different fixed final IBU concentrations, $\mathrm{C}_{2}$. 


\subsection{Some Economic Implications}

To a large extent the benefits or disadvantages of the system described is strongly based on the balance between

the costs associated with the adsorbent savings versus the additional capex and opex costs of installing the two stage adsorption reactors with a corresponding reduction in the adsorption time.

\subsubsection{Plant equipment costs}

In the case of the multistage adsorption system, smaller adsorber vessel reactors would be involved $e . g$. these vessel units would contain the activated adsorbent and incorporate an interstage filter unit in order to separate the spent adsorbent material. Hence, from a practical viewpoint, the multistage plant is better enhancing the process efficiency by minimizing the total amount of adsorbent to be applied and reducing the overall bath processing time.

504 Therefore making the multistage process potentially attractive in economic terms. The larger the number of stages, the greater will be the saving in adsorbent costs, but the total capital equipment costs - for multiple units - will increase and the handling costs will also be increased. Due to these competing influencing factors, the number of batch stages is usually limited to two or three in order to optimize the economic benefits. For this reason, it is usually required to evaluate the minimum quantity of adsorbent in a two-stage process and the associated savings.

\subsubsection{Adsorbent Savings}

511 based carbon that can be conserved by the application of the two-stage adsorber batch reactor versus a single-stage 512 batch adsorber. The total adsorbent quantity applied for the two-stage optimization adsorber based on $99.5 \%$ IBU 513 removal and initial IBU concentrations of 1.0, 2.0, 5.0, 10.0 and $20.0 \mathrm{mg} / \mathrm{L}$ - the amount of activated carbon falls in 514 the range of 4.60 to $2.39 \mathrm{~kg}$ adsorbent as shown in Table 7 for the treatment of $1000 \mathrm{~L}, 1 \mathrm{~m} 3$, of solution. For a 515 single-stage adsorption unit the quantity of the treated date stone carbon required is in the range of 43.3 to $21.2 \mathrm{~kg}$ as 516 shown in Table 7 using equations (6) and (22):

$\frac{S_{S}}{V_{S}}=\frac{C_{0}-C_{2}}{q_{2}-q_{0}}$

517 The extra quantity of adsorbent necessary to perform for the single stage treatment ranges from 9.4 to 8.8 518 times more than the optimized two-stage batch adsorber amount - this is quite substantial.

Table 8. presents the total quantity of date stone derived activated carbon applied for the two-stage batch optimized system to produce a fixed treated effluent limit concentration value of $0.20 \mathrm{mg} / \mathrm{L} \mathrm{IBU}$ removal for initial 
IBU concentrations of 1.0, 2.0, 5.0, 10.0 and $20.0 \mathrm{mg} / \mathrm{L}$ - the quantities of the derived activated carbon adsorbent are $0.206,0.353,0.643,0.976$ and $1.47 \mathrm{~kg}$ for $1000 \mathrm{~L}$ of solution.

For the single-stage batch system equivalency, the quantity of date stone carbon is $9.04,4.47,2.19,0.822$ and $0.365 \mathrm{~kg}$ using equations (6) and (21). The additional quantity of the activated carbon adsorbent necessary for the single-stage batch adsorption system ranges 6.1 times to 1.8 times, demonstrating the advantages for a two-stage process over a single-stage process in terms of adsorbent utilization.

Table 7. Minimum total amount of acid activated date stone carbon for the $99.5 \%$ removal of ibuprofen in single $\left(\mathrm{S}_{\mathrm{S}}\right)$ and two-stage $\left(\mathrm{S}_{\mathrm{S} 1}+\mathrm{S}_{\mathrm{S} 2}\right)$ operations for $\mathrm{C}_{0}$ values and $1000 \mathrm{~L}$ of solution

\begin{tabular}{lccccc}
\hline Variable $\left(\mathbf{C}_{\mathbf{0}}\right)(\mathbf{m g} / \mathbf{L})$ & 1.0 & 2.0 & 5.0 & 10.0 & 20.0 \\
\hline Effluent $\left(\mathbf{C}_{\mathbf{2}}\right)(\mathbf{m g} / \mathbf{L})$ & 0.005 & 0.010 & 0.025 & 0.050 & 0.100 \\
\hline Single Stage $\left(\mathbf{S s}_{\mathbf{s}}\right)(\mathbf{k g})$ & 43.3 & 36.7 & 29.4 & 25.0 & 21.2 \\
\hline Two-Stage $\left(\mathbf{S}_{\mathbf{s} \mathbf{1}}+\mathbf{S}_{\mathbf{s}}\right)(\mathbf{k g})$ & 4.60 & 3.90 & 3.16 & 2.72 & 2.39 \\
\hline qe for single stage $(\mathbf{m g} / \mathbf{g})$ & 0.0230 & 0.0543 & 0.169 & 0.398 & 0.937 \\
\hline
\end{tabular}

Table 8. Minimum total amount of phosphoric acid activated date stone carbon for an IBU effluent concentration of $0.20 \mathrm{mg} / \mathrm{L}$ in both a single $\left(\mathrm{S}_{\mathrm{S}}\right)$ and a two-stage $\left(\mathrm{S}_{\mathrm{S} 1}+\mathrm{S}_{\mathrm{S} 2}\right)$ system for various $\mathrm{C}_{0}$ values for $1000 \mathrm{~L}$ solution

\begin{tabular}{lccccc}
\hline Variable $\left(\mathbf{C}_{\mathbf{0}}\right)(\mathbf{m g} / \mathbf{L})$ & 1.0 & 2.0 & 5.0 & 10.0 & 20.0 \\
\hline Effluent $\left(\mathbf{C}_{\mathbf{2}}\right)(\mathbf{m g} / \mathbf{L})$ & 0.20 & 0.20 & 0.20 & 0.20 & 0.20 \\
\hline Single Stage $\left(\mathbf{S}_{\mathbf{s}}\right)(\mathbf{k g})$ & 0.365 & 0.822 & 2.19 & 4.47 & 9.04 \\
\hline Two-Stage $\left(\mathbf{S}_{\mathbf{s} \mathbf{}}+\mathbf{S}_{\mathbf{s} 2}\right)(\mathbf{k g})$ & 0.206 & 0.353 & 0.643 & 0.976 & 1.47 \\
\hline$q_{\mathrm{e}}$ for Single Stage $(\mathbf{m g} / \mathbf{g})$ & 2.19 & 2.19 & 2.19 & 2.19 & 2.19
\end{tabular}

In Table 8, the effect of a lower effluent discharge concentration has a major impact on the additional amount of adsorbent required in the case of the single stage batch adsorption process, that is, at a discharge limit concentration of $0.005 \mathrm{mg} / \mathrm{L}$, then $43.3 \mathrm{~kg}$ adsorbent are required, that is, 9.4 times the quantity required for the optimized two stage system. In Table 8, the influence of initial concentration is demonstrated and shows that the higher the initial IBU concentration then the greater is the extra amount of carbon: 6.1 times more at $\mathrm{C}_{0}=20 \mathrm{mg} / \mathrm{L}$ and $\mathrm{C}_{\mathrm{e}}=0.20 \mathrm{mg} / \mathrm{L}$ and only 1.8 times the amount of additional carbon at $\mathrm{C}_{0}=1.0 \mathrm{mg} / \mathrm{L}$ and $\mathrm{Ce}=0.20 \mathrm{mg} / \mathrm{L}$. 
Regeneration tests have not been performed due to the problem of available time but conventional regeneration technologies could be applicable for a number of pharmaceuticals which are often recalcitrant in nature. studies were 543 not undertaken in the time available but standard regeneration methods could be considered for this type of 544 recalcitrant compound. IBU does not have any nitrogen or halogen groups therefore regeneration by combustion burning off the pharmaceutical directly is feasible. However, combustion has the inherent disadvantages associated

546 with it including: energy/fuel requirements, greenhouse gas emmissions since carbon dioxide is produced and so contributing to global warming, typically there is a loss of carbon from carbon based adsorbents of the order of 10volatile organic solvents to be recovered and recycled but the high boiling and melting point of the pharmaceutical IBU would render this technique almost impossible. The treatment by the use of a microbial slurry to biodegrade the IBU is a possible alternative approach but IBU is microbiologically reasonably stable against the majority of microorganisms, in addition, this methodology takes quite a lengthy period of time to implement and complete. Solvent extraction seems to be a reasonable approach by using a volatile alcohol having a high solubility for IBU. Then, by making use of one of the on-site batch adsorber units for dissolving the IBU followed by pumping the IBU solution to a vacuum driven evaporation system or vacuum driven stripping column recovering the solvent for recycling and recovering the IBU for recycling too. Several toxic loaded adsorbents are disposed of in hazardous landfill sites

557 frequently after stabilisation by encapsulation or by vitrification although this procedure is expensive and there is no recovery of the adsorbent and the IBU. Longer term detrimental effects of hazardous landfilling include the

559 production of landfill leachate creating environmental problems in-situ site anaerobic degradation to produce methane biogas emissions. Consequently, the application of a volatile solvent extraction stage incorporating solvent recovery, adsorbent regeneration and re-use with potential IBU recovery, offers the most attractive technology opportunity for further investigation.

\section{Conclusion}

Phosphoric acid has been used to treat waste date stone derived char and heated to $550^{\circ} \mathrm{C}$ to produce activated 565 carbon. The BET- $\mathrm{N}_{2}$ surface area of this date stone derived activated carbon is $727 \mathrm{~m}^{2} / \mathrm{g}$, a pore volume of 0.70 $566 \mathrm{~cm}^{3} / \mathrm{g}$ and a pore diameter size $=3.89 \mathrm{~nm}$. The adsorption capacity the active carbon was tested for the adsorption of 567 the ibuprofen and the maximum adsorption capacity carbon product was $126 \mathrm{mg} / \mathrm{g}$, which compared favourably with the very few reported IBU capacities in the literature. Experimental equilibrium data have been modelled applying 
seven isotherm equations, namely, Langmuir, Freundlich, Langmuir-Freundlich, Redlich-Peterson, Temkin, Dubinin-Radushkevic and Toth isotherm models. The Langmuir-Freundlich isotherm provided the optimised best fit correlation based on the application of an SSE error analysis. This correlation was then applied for minimising the amount of date carbon adsorbent needed in designing a two-stage batch adsorber system for the removal of IBU. The quantity of the date stone derived activated carbon was determined for a two-stage batch adsorber and for an equivalent single stage process. The quantity of activated carbon adsorbent require was greatly reduced in the twostage system, sometimes by a factor of more than 9-fold. This optimization study also demonstrated the amount of adsorbent strongly depends on both the IBU concentration and especially the effluent discharge limit value adopted or imposed. The results demonstrate the potential at an industrial scale for designing and performing economic and technical feasibility studies on two-stage and multi-stage batch adsorption process units for the treatment of emerging pollutants.

\section{Declarations}

Ethics approval and consent to participate- Not applicable

Consent for publication- Not applicable

Availability of data and materials

All data generated or analysed during this study are included in this published article [and its supplementary information files].

\section{Competing interests}

The authors declare that they have no competing interests" in this section.

\section{Funding}

The authors would like to thank Qatar National Research Fund for their support of this research through an award NPRP-11S-0117-180328, the Supreme Committee for Delivery and Legacy (SCDL) and to Hamad Bin Khalifa University, Qatar Foundation, for an award to HF. Any opinions, findings and conclusions, or recommendations expressed in this material are those of the author(s) and do not necessarily reflect the views of HBKU or QF or SCDL.

\section{Authors' contribution}

HF- Investigation, Validation, Writing - Original Draft.

JS- Conceptualization, Project administration, Methodology, Writing - Review \& Editing. 
GM- Funding acquisition, Conceptualization, Resources, Project administration. Supervision, Methodology,

PP- Formal analysis.

All authors read and approved the final manuscript."

\section{Acknowledgements}

The authors wish to thank Hamad Bin Khalifa University (HBKU), Qatar Energy and Environment Research Institute (QEERI), and Qatar Foundation (QF), for their patronage.

\section{Authors' information}

\begin{tabular}{|c|c|c|}
\hline Name & Email & Contact address \\
\hline Hajar Farzaneh & hajfarzaneh@hbku.edu.qa & $\begin{array}{l}\text { Division of } \\
\text { Development, College of Science } \\
\text { and Engineering, Hamad Bin } \\
\text { Khalifa University (HBKU), Qatar } \\
\text { Foundation (QF), Doha, Qatar. }\end{array}$ \\
\hline $\begin{array}{l}\text { Dr. Jayaprakash } \\
\text { Saththasivam }\end{array}$ & jsaththasivam@hbku.edu.qa & $\begin{array}{l}\text { Qatar Energy and Environment } \\
\text { Research Institute, Hamad Bin } \\
\text { Khalifa University (HBKU), Qatar } \\
\text { Foundation (QF), Doha, Qatar. }\end{array}$ \\
\hline $\begin{array}{l}\text { Prof. Dr. Gordon } \\
\text { Mckay }\end{array}$ & gmckay@hbku.edu.qa & $\begin{array}{l}\text { Division of Sustainable } \\
\text { Development, College of Science } \\
\text { and Engineering, Hamad Bin } \\
\text { Khalifa University (HBKU), Qatar } \\
\text { Foundation (QF), Doha, Qatar. }\end{array}$ \\
\hline $\begin{array}{l}\text { Dr. Prakash } \\
\text { Parthasarathy }\end{array}$ & $\begin{array}{l}\text { pparthasarathy@hbku.edu.qa, } \\
\text { prakrock@gmail.com }\end{array}$ & $\begin{array}{l}\text { Division of } \text { Sustainable } \\
\text { Development, College of Science } \\
\text { and Engineering, Hamad Bin } \\
\text { Khalifa University (HBKU), Qatar } \\
\text { Foundation (QF), Doha, Qatar. }\end{array}$ \\
\hline
\end{tabular}

\section{References}

Akaike H (1998) Information Theory and an Extension of the Maximum Likelihood Principle. In: Parzen E, Tanabe

Al-Ghouti MA, Li J, Salamh Y, et al (2010) Adsorption mechanisms of removing heavy metals and dyes from aqueous solution using date pits solid adsorbent. J Hazard Mater 176:510-520.

$$
\text { https://doi.org/10.1016/j.jhazmat.2009.11.059 }
$$

Almanassra IW, Kochkodan V, Ponnusamy G, et al (2020) Carbide Derived Carbon (CDC) as novel adsorbent for ibuprofen removal from synthetic water and treated sewage effluent. J Environ Heal Sci Eng 36:. https://doi.org/10.1007/s40201-020-00554-0

Baccar R, Sarrà M, Bouzid J, et al (2012) Removal of pharmaceutical compounds by activated carbon prepared from 
agricultural by-product. Chem Eng J 211-212:310-317. https://doi.org/10.1016/j.cej.2012.09.099

Badmus KO, Tijani JO, Massima E, Petrik L (2018) Treatment of persistent organic pollutants in wastewater using hydrodynamic cavitation in synergy with advanced oxidation process. Environ. Sci. Pollut. Res. 25:72997314

Belhamdi B, Merzougui Z, Trari M, Addoun A (2016) A kinetic, equilibrium and thermodynamic study of Lphenylalanine adsorption using activated carbon based on agricultural waste (date stones). J. Appl. Res. Technol. 14:354-366

Borikar D, Mohseni M, Jasim S (2014) Evaluation and Comparision of Conventional and Advanced Oxidation Processes for the Removal of PPCPs and EDCs and Their Effect on THM-Formation Potentials. Ozone Sci Eng 37-41. https://doi.org/10.1080/01919512.2014.940028

Bouchemal N, Azoudj Y, Merzougui Z, Addoun F (2012) Adsorption modeling of orange G dye on mesoporous activated carbon prepared from algerian date pits using experimental designs. Desalin Water Treat 45:284-290. https://doi.org/10.1080/19443994.2012.692042

Bouhamed F, Elouear Z, Bouzid J (2012) Adsorptive removal of copper(II) from aqueous solutions on activated carbon prepared from Tunisian date stones: Equilibrium, kinetics and thermodynamics. J Taiwan Inst Chem Eng 43:741-749. https://doi.org/10.1016/j.jtice.2012.02.011

Chen B, Chi Wai Hui, McKay G (2001) Film-pore diffusion modeling and contact time optimization for the adsorption of dyestuffs on pith. Chem Eng J 84:77-94. https://doi.org/10.1016/S1385-8947(01)00193-0

Cherik D, Louhab K (2017) Preparation of microporous activated carbon from date stones by chemical activation using zinc chloride. Energy Sources, Part A Recover Util Environ Eff 39:1935-1941. https://doi.org/10.1080/15567036.2017.1390012

Danish M, Hashim R, Ibrahim MNM, Sulaiman O (2014) Optimized preparation for large surface area activated carbon from date (Phoenix dactylifera L.) stone biomass. Biomass and Bioenergy 61:167-178. https://doi.org/10.1016/j.biombioe.2013.12.008

Darweesh TM, Ahmed MJ (2017) Batch and fixed bed adsorption of levofloxacin on granular activated carbon from date (Phoenix dactylifera L.) stones by KOH chemical activation. Environ Toxicol Pharmacol 50:159-166. https://doi.org/10.1016/j.etap.2017.02.005

De Vargas JPR, Bastos MC, Al Badany M, et al (2021) Pharmaceutical compound removal efficiency by a small 
constructed wetland located in south Brazil. Environ Sci Pollut Res 1-20. https://doi.org/10.1007/s11356-021$12845-6$

Dubinin MM (1960) The potential theory of adsorption of gases and vapors for adsorbents with energetically nonuniform surfaces. Chem Rev 60:235-241. https://doi.org/10.1021/cr60204a006

Farzaneh H, Loganathan K, Saththasivam J, McKay G (2020) Selectivity and competition in the chemical oxidation processes for a binary pharmaceutical system in treated sewage effluent. Sci Total Environ. https://doi.org/10.1016/j.scitotenv.2020.142704

Freundlich HMF (1906) Over the adsorption in solution. J Phys Chem 57:385-470

Gallego-Ríos SE, Atencio-García VJ, Peñuela GA (2021) Effect of ibuprofen in vivo and in vitro on the sperm quality of the striped catfish Pseudoplatystoma magdaleniatum. Environ Sci Pollut Res 1-9. https://doi.org/10.1007/s11356-021-13245-6

Girgis BS, El-Hendawy ANA (2002) Porosity development in activated carbons obtained from date pits under chemical activation with phosphoric acid. Microporous Mesoporous Mater 52:105-117. https://doi.org/10.1016/S1387-1811(01)00481-4

Golovko O, de Brito Anton L, Cascone C, et al (2020) Sorption Characteristics and Removal Efficiency of Organic Micropollutants in Drinking Water Using Granular Activated Carbon (GAC) in Pilot-Scale and Full-Scale Tests. Water 12:2053. https://doi.org/10.3390/w12072053

Guedidi H, Reinert L, Lévêque JM, et al (2013) The effects of the surface oxidation of activated carbon, the solution $\mathrm{pH}$ and the temperature on adsorption of ibuprofen. Carbon N Y 54:432-443. https://doi.org/10.1016/j.carbon.2012.11.059

Guedidi H, Reinert L, Soneda Y, et al (2017) Adsorption of ibuprofen from aqueous solution on chemically surfacemodified activated carbon cloths. Arab J Chem 10:S3584-S3594. https://doi.org/10.1016/j.arabjc.2014.03.007

Hameed BH, Salman JM, Ahmad AL (2009) Adsorption isotherm and kinetic modeling of 2,4-D pesticide on activated carbon derived from date stones. J Hazard Mater 163:121-126. https://doi.org/10.1016/j.jhazmat.2008.06.069

Hassan SS, Al-Ghouti MA, Abu-Dieyeh M, McKay G (2020) Novel bioadsorbents based on date pits for organophosphorus pesticide remediation from water. J Environ Chem Eng 8:103593. https://doi.org/10.1016/j.jece.2019.103593 
671 Hijab M, Sali S, Mckay G (2018) Dye removal from water using date pit derived activated carbon. In: World

672

673

674

675

676

677

678

679

680

681

682

683

684

685

686

687

688

689

690

691

692

693

694

695

696

697

698

Conference on Carbon

Hijab MS, Parthasarathy P, Li P, et al (2020) Active carbon from microwave date stones for toxic dye removal: setting the design capacity. Chem Eng Technol 43:1841-1849. https://doi.org/10.1002/ceat.202000059

Kishor R, Purchase D, Saratale GD, et al (2021) Ecotoxicological and health concerns of persistent coloring pollutants of textile industry wastewater and treatment approaches for environmental safety. J Environ Chem Eng 9:105012. https://doi.org/10.1016/j.jece.2020.105012

Kudlek E (2018) Decomposition of Contaminants of Emerging Concern in Advanced Oxidation Processes. Water 10:955. https://doi.org/10.3390/w10070955

Kumar A, Pal D (2018) Antibiotic resistance and wastewater: Correlation, impact and critical human health challenges. J. Environ. Chem. Eng. 6:52-58

Kumar KV, Sivanesan S (2006) Pseudo Second Order Kinetics and Pseudo Isotherms for Malachite Green onto Activated Carbon: Comparison of Linear and Non-Linear Regression Methods. J Hazard Mater 136:721-726. https://doi.org/https://doi.org/10.1016/j.jhazmat.2006.01.003

Langmuir I (1916) The constitution and fundamental properties of solids and liquids. J Am Chem Soc 38:2221-2295

Mangwandi C, Kurniawan TA, Albadarin AB (2020) Comparative biosorption of chromium (VI) using chemically modified date pits (CM-DP) and olive stone (CM-OS): Kinetics, isotherms and influence of co-existing ions. Chem Eng Res Des 156:251-262. https://doi.org/10.1016/j.cherd.2020.01.034

Merzougui Z, Azoudj Y, Bouchemel N, Addoun F (2011) Effect of activation method on the pore structure of activated carbon from date pits application to the treatment of water. Desalin Water Treat 29:236-240. https://doi.org/10.5004/dwt.2011.1420

Messaoudi N El, Khomri M El, Bentahar S, et al (2016) Removal of crystal violet by biosorption onto date stones. Sci Study Res Chem Chem Eng 17:151-167(17)

Mestre AS, Bexiga AS, Proença M, et al (2011) Activated carbons from sisal waste by chemical activation with K 2CO 3: Kinetics of paracetamol and ibuprofen removal from aqueous solution. Bioresour Technol 102:82538260. https://doi.org/10.1016/j.biortech.2011.06.024

Mestre AS, Pires J, Nogueira JMF, et al (2009) Waste-derived activated carbons for removal of ibuprofen from solution: Role of surface chemistry and pore structure. Bioresour Technol 100:1720-1726. 
https://doi.org/10.1016/j.biortech.2008.09.039

700

701

702

703

704

705

706

707

708

709

710

711

712

713

714

715

716

717

718

719

720

721

722

723

724

725

726

Mui ELK, Cheung WH, McKay G (2010a) Tyre char preparation from waste tyre rubber for dye removal from effluents. J Hazard Mater 175:151-158. https://doi.org/10.1016/j.jhazmat.2009.09.142

Mui ELK, Cheung WH, Valix M, McKay G (2010b) Dye adsorption onto char from bamboo. J Hazard Mater 177:1001-1005. https://doi.org/10.1016/j.jhazmat.2010.01.018

Nassiri Koopaei N, Abdollahi M (2017) Health risks associated with the pharmaceuticals in wastewater. DARU, J. Pharm. Sci. 25

Ponnusamy G, Francis L, Loganathan K, et al (2019) Removal of cyanotoxins in drinking water using ozone and ozone-hydrogen peroxide (peroxone). J Water Supply Res Technol 1-11. https://doi.org/10.2166/aqua.2019.028

Rathner R, Petz S, Tasnádi G, et al (2017) Monitoring the kinetics of biocatalytic removal of the endocrine disrupting compound 17 $\alpha$-ethinylestradiol from differently polluted wastewater bodies. J Environ Chem Eng 5:1920-1926. https://doi.org/10.1016/j.jece.2017.03.034

Redlich O, Peterson DL (1959) A Useful Adsorption Isotherm. J Phys Chem A 63:1024-1026

Rodriguez-Mozaz S, Chamorro S, Marti E, et al (2015) Occurrence of antibiotics and antibiotic resistance genes in hospital and urban wastewaters and their impact on the receiving river. Water Res 69:234-242. https://doi.org/10.1016/j.watres.2014.11.021

Sadraei R (2020) Fast, green and easy adsorption of dye and emerging contaminants by functionalized $\gamma$-AACH. J Environ Chem Eng 8:103616. https://doi.org/10.1016/j.jece.2019.103616

Saleem J, Shahid U Bin, Hijab M, et al (2019) Production and applications of activated carbons as adsorbents from olive stones. Biomass Convers. Biorefinery 9:775-802

Schröder P, Helmreich B, Škrbić B, et al (2016) Status of hormones and painkillers in wastewater effluents across several European states — considerations for the EU watch list concerning estradiols and diclofenac. Environ Sci Pollut Res 23:12835-12866. https://doi.org/10.1007/s11356-016-6503-x

Shon HK, Vigneswaran S, Snyder S a. (2006) Effluent Organic Matter (EfOM) in Wastewater: Constituents, Effects, and Treatment. Crit Rev Environ Sci Technol 36:327-374. https://doi.org/10.1080/10643380600580011

Sips R (1948) Combined Form of Langmuir and Freundlich Equations. J Chem Phys 16:490-495

Suresh Kumar Reddy K, Al Shoaibi A, Srinivasakannan C (2013) A comparison of microstructure and adsorption 
characteristics of activated carbons by $\mathrm{CO} 2$ and $\mathrm{H} 3 \mathrm{PO} 4$ activation from date palm pits. Carbon N Y 52:623. https://doi.org/10.1016/j.carbon.2012.10.021

729 Temkin MJ, Pyzhev V (1940) Recent Modifications to Langmuir Isotherms. Acta Physiochim USSR 217-222

730 To MH, Hadi P, Hui CW, et al (2017) Mechanistic study of atenolol, acebutolol and carbamazepine adsorption on waste biomass derived activated carbon. J Mol Liq 241:386-398. https://doi.org/10.1016/j.molliq.2017.05.037

732 Toth J (1971) State equation of the solid gas interface layer. Acta Chim (Academiae Sci Hungaricae 69:311-317

733 Tran NH, Li J, Hu J, Ong SL (2014) Occurrence and suitability of pharmaceuticals and personal care products as molecular markers for raw wastewater contamination in surface water and groundwater. Environ Sci Pollut Res 21:4727-4740. https://doi.org/10.1007/s11356-013-2428-9

Westerhoff P, Yoon Y, Snyder S, Wert E (2005) Fate of Endocrine-Disruptor, Pharmaceutical, and Personal Care Product Chemicals during Simulated Drinking Water Treatment Processes Fate of Endocrine-Disruptor, Pharmaceutical, and Personal Care Product Chemicals during Simulated Drinking Water Treat. Environ Sci Technol 39:6649-6663. https://doi.org/10.1021/es0484799 onto chitosan. J Appl Polym Sci 92:1633-1645. https://doi.org/10.1002/app.13714 
Figures

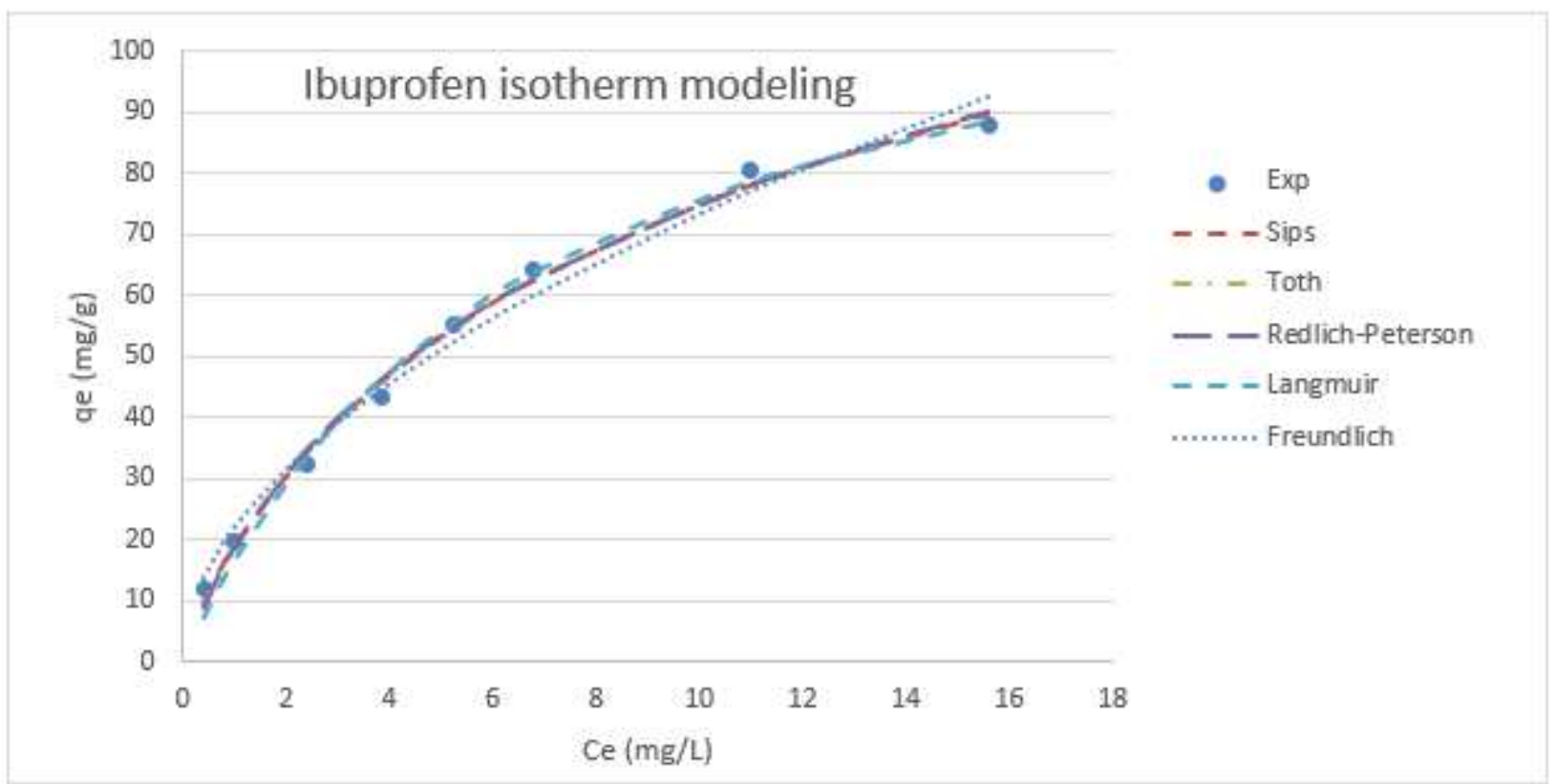

Figure 1

Five isotherm models compared with the experimental IBU equilibrium data.

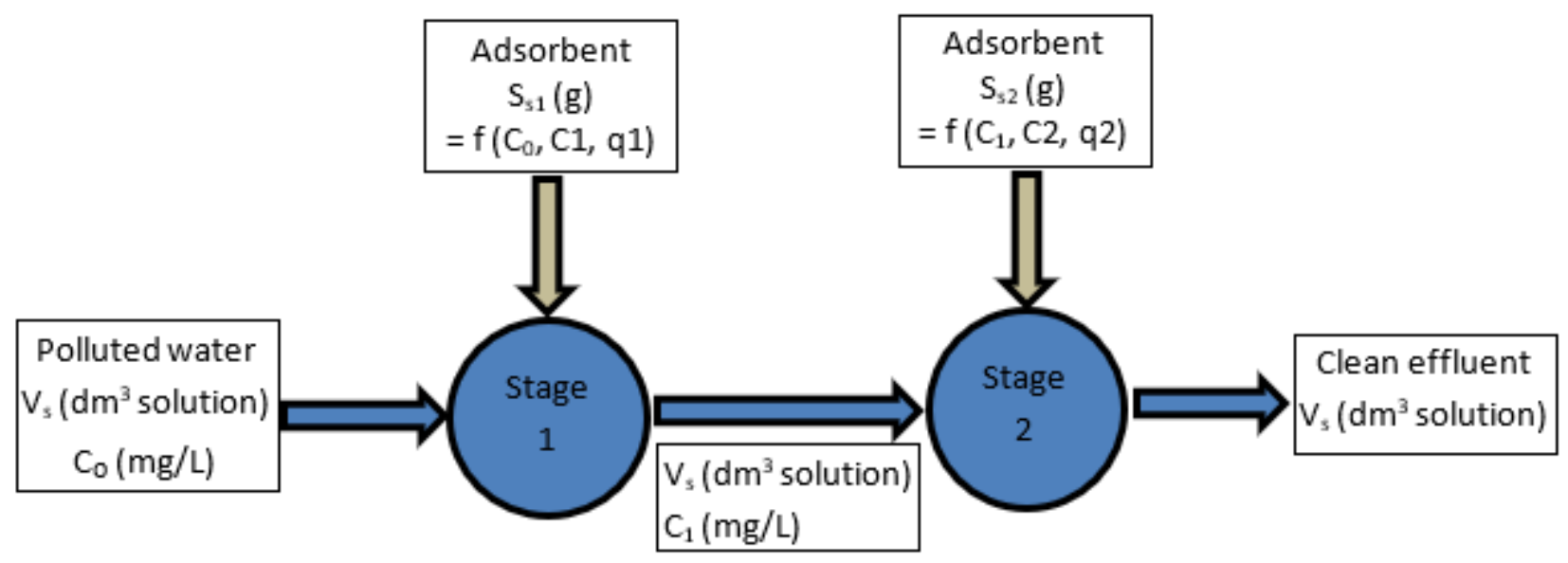

Figure 2

Schematic figure of a two-stage system 


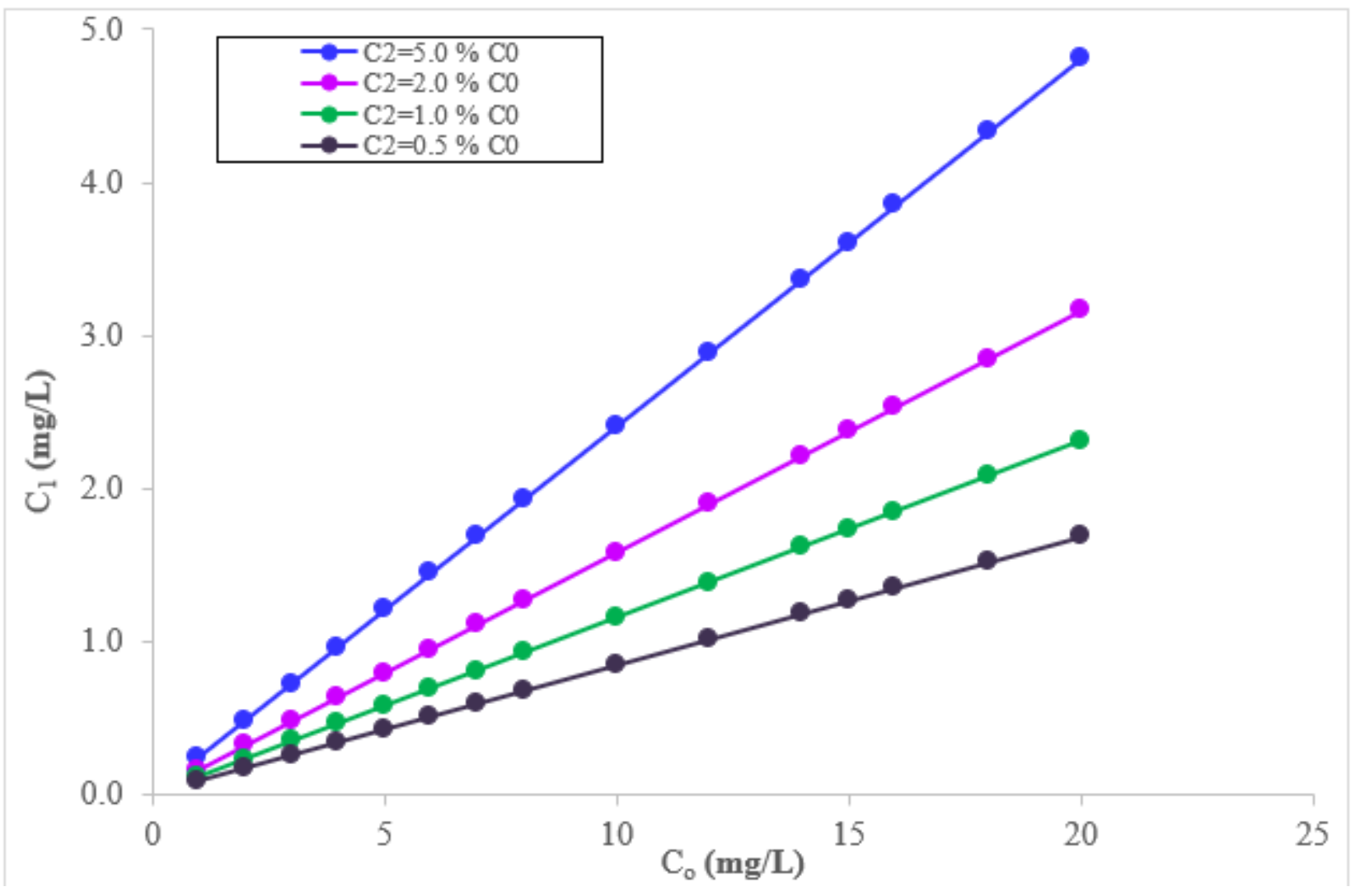

Figure 3

Interstage concentrations, C1, to remove different fixed \% CO IBU using the Langmuir-Freundlich model.

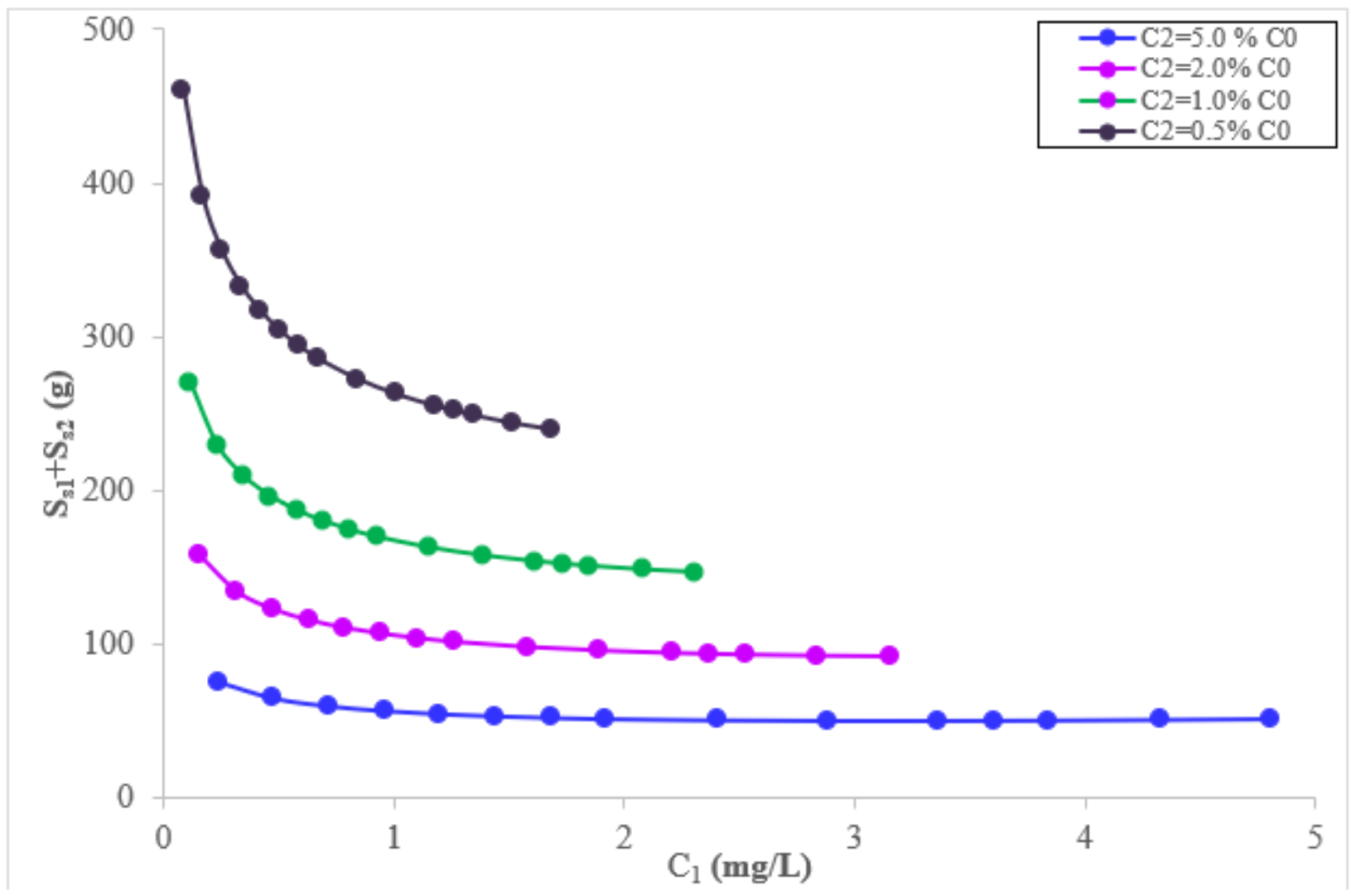

Figure 4 
Minimum quantity of acid treated date stone activated carbon, $S 1+S 2$, against the interstage concentrations, $\mathrm{C} 1$, to remove IBU using the Langmuir-Freundlich model for different removal values, \% $\mathrm{CO}$.

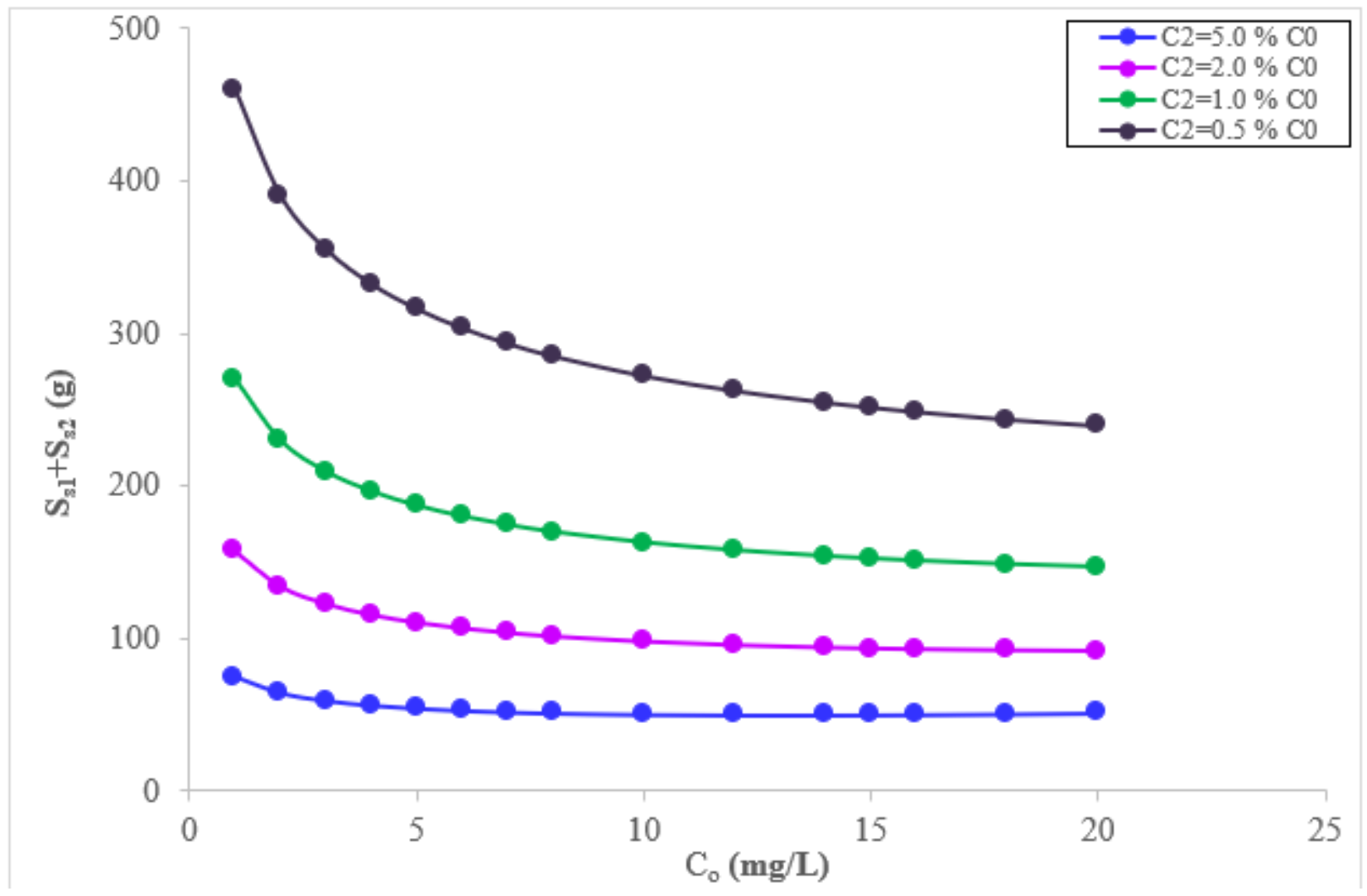

\section{Figure 5}

Minimum total quantity of acid treated date stone activated carbon, $S 1+S 2$, against the initial IBU concentration, $\mathrm{CO}$, to remove a fixed \% $\mathrm{CO}$ IBU using the Langmuir-Freundlich model. 


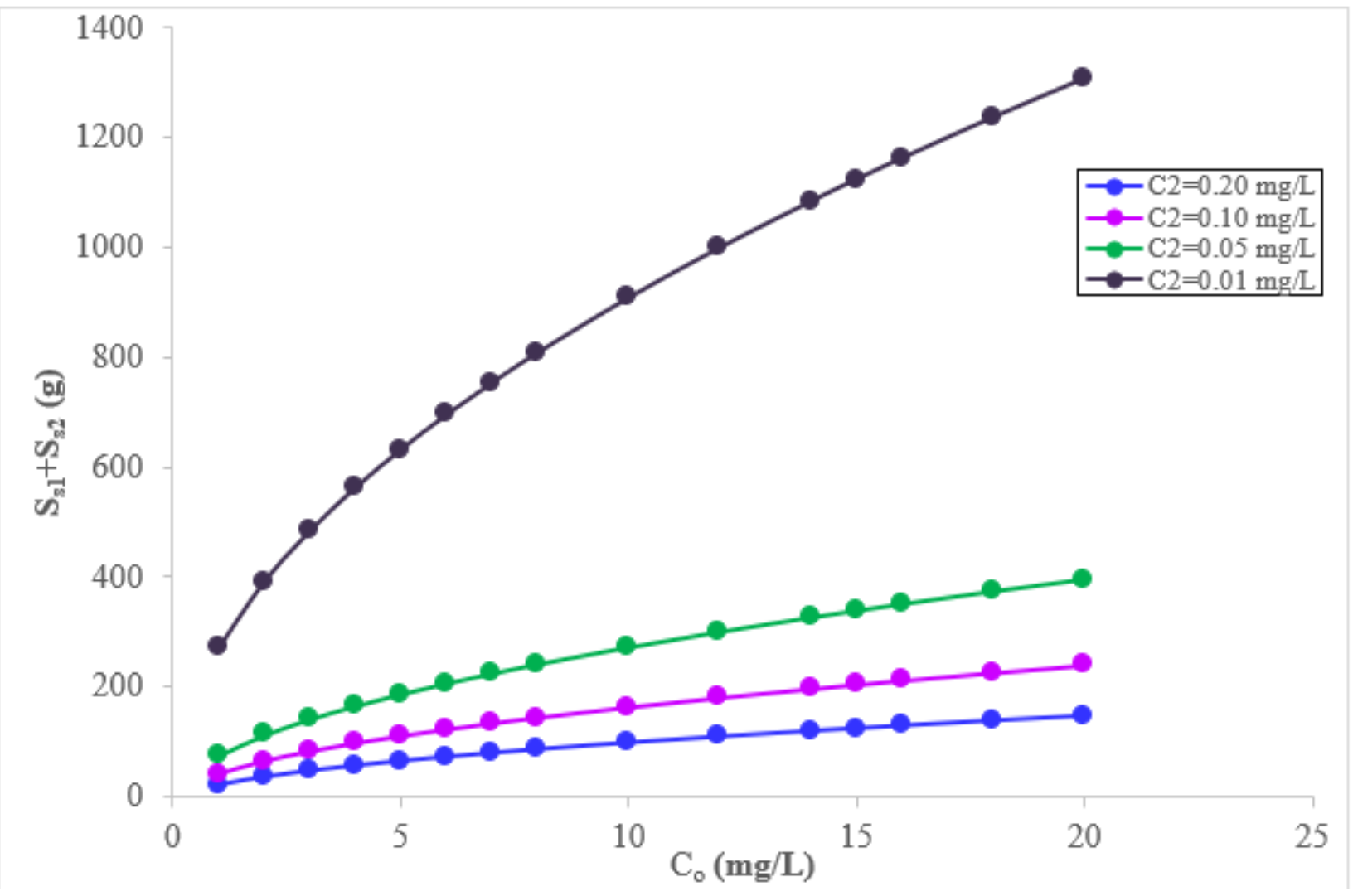

Figure 6

Minimum total quantuty of acid treated date stone carbon, $S 1+S 2$, to remove IBU applying the LangmuirFreundlich model at different initial IBU concentrations, $\mathrm{CO}$, for different set values of final IBU concentrations, $\mathrm{C} 2$, in the effluent 


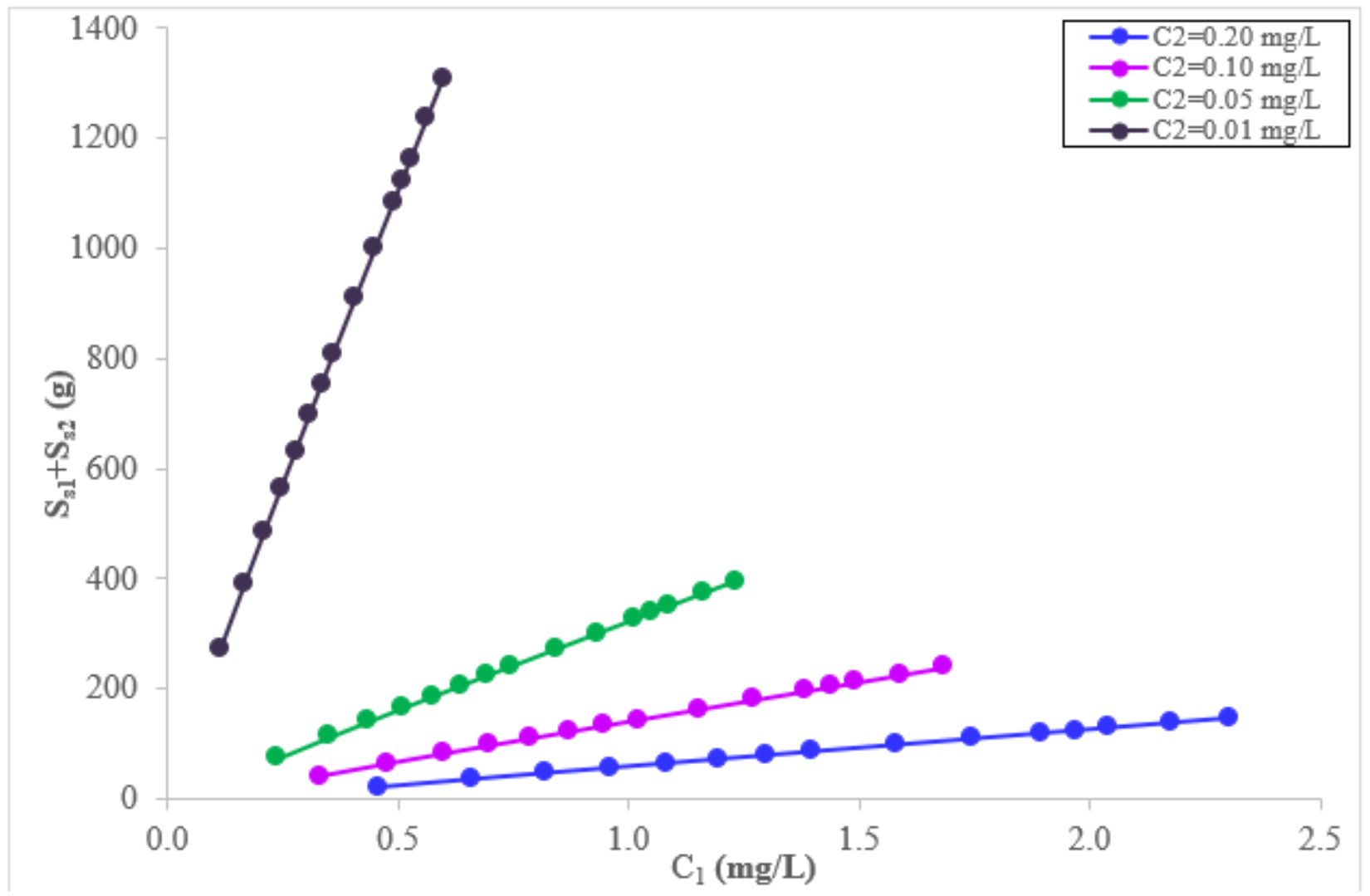

\section{Figure 7}

Minimum quantity of acid treated date stone carbon, $\mathrm{S} 1+\mathrm{S} 2$, to remove IBU against the interstage IBU concentration, $\mathrm{C} 1$, using the Langmuir-Freundlich model for the set values of final IBU concentrations in the effluent, $\mathrm{C} 2$.

\section{Supplementary Files}

This is a list of supplementary files associated with this preprint. Click to download.

- SupplementaryInformation.docx 